\title{
WHOSE RIGHT AND WHO'S RIGHT? THE US SUPREME COURT V. THE EUROPEAN COURT OF HUMAN RIGHTS ON CORPORATE EXERCISE OF RELIGION
}

\author{
Ioana Cismas $\dagger$ and Stacy Cammarano
}

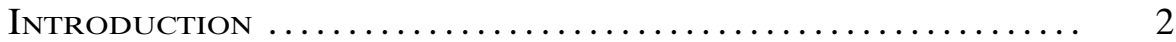

I. Whose Right is the Exercise of Religion? .......... 4

A. In the USA: Hobby Lobby Decides................. 4

1. Corporate Form $\ldots \ldots \ldots \ldots \ldots \ldots \ldots \ldots \ldots \ldots \ldots$

2. Profit-Making Objective ................... 7

3. Manifestations of Religion $\ldots \ldots \ldots \ldots \ldots \ldots \ldots, 7$

B. "European" Freedom of Religion .................. 8

1. Corporate Form ........................ 9

2. (Non) Profit-making and Religious or

Philosophical Objects ..................... 10

3. Manifestations of Religion .................. 13

C. Alternative Paths of Interpretation ................ 15

1. Legal Separation Between Shareholders and

Company in US Law ....................... 16

2. Standing $\ldots \ldots \ldots \ldots \ldots \ldots \ldots \ldots \ldots \ldots \ldots \ldots \ldots \ldots, 21$

II. Limitations on Religious Freedom on both sides of the Atlantic ............................... 27

A. The ACA's Contraceptive Mandate: Testing the Limits . 27

B. "European" Limitations on Religious Freedom: On

Veils and Margins ........................... 30

C. Competing Rights: On Majorities and Minorities ....... 33

III. In the Aftermath of Hobby LobBy .............. 34

A. Corporate Influence, the Sorting of Society and Polarization ................................ 35

B. Losing the Balance: Women, Employees and

"Targeted" Groups ........................... 40

Conclusion............................................. 43

$\dagger$ Dr. Ioana Cismas, Lecturer at Stirling Law School, Scotland, UK. The author's research was supported by a Swiss National Science Foundation grant.

\$ Stacy Cammarano, Esq., former Managing Director of the Center for Human Rights and Global Justice at New York University School of Law. Stacy would like to thank Eric Berelovich for his thoughtful comments on this paper. Both authors would like to thank Peter Speelman for his research assistance. The views expressed in this article are the authors' personal views and do not necessarily reflect the views of the institutions with which they are affiliated. 


\section{Abstract}

This article contrasts the United States Supreme Court's decision in Burwell v. Hobby Lobby Stores on corporations' ability to exercise religion with relevant jurisprudence of the European Convention on Human Rights ("ECHR") mechanisms - the European Court of Human Rights and the now-defunct European Commission on Human Rights. We seek to determine "whose right and who's right?" In other words, does a corporate right to exercise religion exist? And is the Supreme Court right in recognizing that protection for for-profit entities, or is the European Court of Human Rights correct in denying it? We demonstrate that the Supreme Court sidesteps a rich body of US case law on corporate form that recognizes the separation of the corporate entity from its officers. Instead, the Supreme Court confers the owner's beliefs onto the corporation itself, a tactic that would be useful under the associational standing doctrine but that should still not apply to Hobby Lobby. Both US law and European mechanisms' jurisprudence could have provided valuable insights for alternative models; foremost, the distinction between non-profit and for-profit enterprises and the recognition that only corporations whose membership came together for the purpose of exercising religion - in other words non-profit religious associations - should be able to assert religious beliefs on behalf of their membership. We argue that the Supreme Court's recognition of a corporation's ability to exercise religion in Hobby Lobby will have negative legal consequences. We explore the decision's potential to diminish the reproductive and healthcare rights of women and employees, legitimize discriminatory conduct by corporations towards LGBTQ individuals, and deepen ideological sorting and polarization in society.

\section{INTRODUCTION}

Hobby Lobby, a company that should only be an arts-and-crafter's dream, has become a lawyer's conundrum. To be precise, this puzzle emerges from the United States Supreme Court ("Supreme Court") holding in Burwell v. Hobby Lobby Stores ("Hobby Lobby") that the contraceptive mandate in the Patient Protection and Affordable Care Act ("ACA") violated the Religious Freedom Restoration Act of 1993 ("RFRA") because the mandate substantially burdened the religious beliefs of the three closely-held corporations ("CHCs") in the case. ${ }^{2}$

The Court placed Hobby Lobby Stores ("Hobby Lobby"), Mardel, and Conestoga Wood Specialty Corporation ("Conestoga") at the intersection of two of the most thrilling social and legal debates of our times. Upon reading the Court's decision, the lawyer - as well as the sensible

1134 S. Ct. 2751 (2014).

${ }^{2} I d$. at 2759. 
hobby bricoleur - would wonder how far corporate "human" rights can and should go and whether such rights can and should be correlated to responsibilities. They would also consider a variant of the separation of church and state question and inquire into the extent to which the state should protect human rights from religious interference.

The decision has important implications for human rights; in particular, it weakens the protection of reproductive and healthcare rights and poses possible threats to freedom from discrimination based on gender and sexual orientation. While this article discusses some of these consequences, its primary aim is to explore a more basic aspect: which type of entity can hold and exercise religious views. It is this aspect that we identify as the source of potential socio-legal conflict in the United States. The analysis compares the Supreme Court's reasoning on corporate form, profit-making objective, and limitations to religious exercise in Hobby Lobby ${ }^{3}$ to relevant jurisprudence of the European Convention on Human Rights ("ECHR" or "Convention") mechanisms - namely, the European Court of Human Rights ("European Court") and the now-defunct European Commission on Human Rights ("Commission"). ${ }^{4}$ The comparative study allows us to answer the core questions: Whose right and who's right? That is, does a corporate right to exercise religion exist? And is the Supreme Court right in granting such protection to for-profit entities, or is the European Court correct in denying it?

Looking for inspiration outside the realm of US case law, to Europe, proves an intricate endeavor, given the different structure of the European Court (as a supra-national court overseeing forty-seven sovereign states) and the reticence of many in the US to recognize any value gained from comparing foreign judgments. Despite these caveats, the parallel between the two jurisdictions provides a full account of how the interpretations on corporate religious freedom differ and offers avenues for alternative interpretation.

The first part of the article summarizes the Supreme Court's treatment in Hobby Lobby of for-profit corporations as "persons" that can exercise freedom of religion under the RFRA, and also identifies non-profit organizations with religious or philosophical objects as exclusive corporate right-holders in the jurisprudence of the European Court and Commission. We proceed to discuss the Supreme Court's (mis)interpretation and neglect of the legal separation between shareholders and company and the standing requirement in US law. We draw on the insights gained

\footnotetext{
3 Id. at 2751.

4 The European Commission on Human Rights operated until 1998, when it was abolished by Protocol No. 11. Protocol No. 11 to the Convention for the Protection of Human Rights and Fundamental Freedoms, Restructuring the Control Machinery Established Thereby, entered into force Nov. 1, 1998, E.T.S. No. 155 (amending the Convention for the Protection of Human Rights and Fundamental Freedoms) [hereinafter Protocol 11] (restructuring the control machinery thereby established).
} 
from European practice to delineate alternative approaches. The second part of the article focuses on the Supreme Court's treatment of state limitations to corporate religious freedom in Hobby Lobby and also looks to the ECHR mechanisms' practice of restricting manifestations of religion under the ECHR. The aim here is to explore whether cross-fertilization presents a potential platform to mitigate the shortcomings of the two jurisdictions in casu. In the third part, the article unearths some of the socio-legal consequences brought about by the findings in Hobby Lobby. In general, we argue that the exercise of religious freedom by for-profit corporations leads to social polarization. In relation to the contraceptive mandate in the ACA, in particular, we identify a number of societal groups that will disproportionally suffer from the judgment's nocuous effects.

\section{Whose Right is the Exercise of Religion?}

\section{A. In the USA: Hobby Lobby Decides}

In 2014, the Supreme Court handed down its decision in Burwell v. Hobby Lobby. ${ }^{5}$ The Supreme Court held that the contraceptive mandate in the ACA violated the RFRA because it substantially burdened the religious beliefs of the three CHCs in the suit, Hobby Lobby, Mardel, and Conestoga, and in doing so, the legislation had not used the least restrictive means. ${ }^{6}$

The RFRA provides that the "government shall not substantially burden a person's exercise of religion even if the burden results from a rule of general applicability" unless it is "in furtherance of a compelling governmental interest," and it is "the least restrictive means of furthering that compelling governmental interest." 7 Hobby Lobby raises a two-part question: whether corporations are "persons" under the RFRA, and whether they can exercise freedom of religion. ${ }^{8}$ The answer to this question turns on the interpretation of three elements under the RFRA: (a) corporate form, (b) profit-making objective, and (c) manifestations of religion. ${ }^{9}$

For the purposes of the comparison with the European human rights system, this two-part question is most salient since the ECHR mechanisms have established strict parameters for what types of organizations can exercise religion. ${ }^{10}$ As such, the type of organization bringing a claim is dispositive for religious exercise claims in the European Court's prac-

5134 S. Ct. 2751 (2014).

6 Id. at 2759.

742 U.S.C. $\$ 2000 b b-1$ (2012).

8 Hobby Lobby, 134 S. Ct. at 2767-68.

9 See discussions infra Section I(A)(1)-(3).

10 See discussion infra Section I(B). 
tice, and we will argue here that it should have been a crucial element in the Supreme Court's analysis as well. ${ }^{11}$

As to the issue of personhood, the Supreme Court held that "person" under the RFRA "include[s] corporations, companies, associations, firms, partnerships, societies, and joint stock companies, as well as individuals" as defined in the Dictionary Act ${ }^{12}$ which instructs courts on rules of interpretation and grammatical construction as applied to federal statutes definitions. ${ }^{13}$ According to the majority, there was no evidence that Congress intended the RFRA to deviate from the Dictionary Act definition of "person"; 14 the majority found it inconceivable that non-profit corporations could be "persons" and benefit from RFRA protections while forprofit corporations be excluded. ${ }^{15}$ The majority relied on three previous cases $^{16}$ to reach this conclusion: Hosanna-Tabor Evangelical Lutheran Church and School v. E.E.O.C. ${ }^{17}$ Gonzales v. O Centro Espírita Beneficente União do Vegetal, ${ }^{18}$ and Church of the Lukumi Babalu Aye, Inc. v. City of Hialeah. ${ }^{19}$

In the dissent, Justice Ginsburg pointed to a key distinction between the non-profit and religious nature of the entities in the cases the majority referenced, and the for-profit corporations at issue in Hobby Lobby. ${ }^{20}$ Ginsburg noted that religious organizations "exist to foster the interests of persons subscribing to the same religious faith." ${ }^{21}$ For-profit corporations, on the other hand, have a diverse constitution of employees and officers. ${ }^{22}$ Although corporations may serve certain ancillary charitable objectives, they do not "serve a community of believers," and the law has long treated them distinctively from religious organizations. ${ }^{23}$ This dis-

11 See id.

12 Hobby Lobby, 134 S. Ct. at 2768.

13 See generally 1 U.S.C. $\S 1$. Congress updated the Dictionary Act most recently in 2002 .

14 Hobby Lobby, 134 S. Ct. at 2768. On the contrary, the dissent noted that the Dictionary Act only applies when the context does not indicate something else. Here, Justice Ginsburg argued, RFRA's reference to a "person's exercise of religion" provides such context in conjunction with her interpretation of case law that for-profit corporations cannot exercise religion. Id. at 2793-94 (Ginsburg, J., dissenting).

15 Id. at 2769 (majority opinion).

16 Id. at 2768-69.

17132 S. Ct. 694 (2012) (lawsuit brought against church which invoked Free Exercise clause as a bar).

18546 U.S. 418 (2006) (RFRA claim brought by church organized as non-profit in New Mexico).

19508 U.S. 520 (1993) (Free Exercise claim brought by church organized as nonprofit in Florida).

20 See Hobby Lobby, 134 S. Ct. at 2797 (Ginsburg, J., dissenting).

21 Id. at 2795.

22 Id. at 2797.

23 Id. at 2796-97. 
tinction in Ginsburg's dissent, ${ }^{24}$ is key in the jurisprudence of the European Court and Commission, as we will argue below.

The majority further held in Hobby Lobby that the three CHCs at issue could exercise religion for the purposes of the RFRA. ${ }^{25}$ It noted that neither the corporate form nor the profit making objective precluded the corporations at issue from exercising religion and that "exercise of religion" is construed broadly to encompass the actions of Hobby Lobby, Mardel, and Conestoga. ${ }^{26}$ The inclusion of corporations as "persons" under the RFRA is fundamentally tied to the question of whether corporations can exercise religion under the RFRA. ${ }^{27}$ According to the majority, such inclusion is meant to protect the rights of the individuals shareholders, officers, and employees - who comprise the corporation. ${ }^{28}$ Although the Third Circuit held that corporations cannot exercise religion because they cannot act separate and apart from their owners and employees, the Supreme Court dispatched that argument. ${ }^{29}$ Just as corporations are "persons" in order to protect the rights and obligations of the individuals who comprise it, according to the majority, RFRA protection extends to the corporation's beliefs in order to protect the beliefs of the individuals who comprise it. ${ }^{30}$

\section{Corporate Form}

With little explanation, the Supreme Court held that corporate form itself was not a bar to exercising religion because non-profit corporations - still using a corporate form - can exercise religion. ${ }^{31}$ The dissent shed marginally more light on the relationship between the corporate form and the corporations' ability to exercise religion: "By incorporating a business, however, an individual separates herself from the entity and escapes personal responsibility for the entity's obligations. One might ask why the separation should hold only when it serves the interest of those who control the corporation." 32

24 See id.

$25 I d$. at 2769-70 (majority opinion).

26 Id.

27 See id.

28 Id. at 2768 ("A corporation is simply a form of organization used by human beings to achieve desired ends. An established body of law specifies the rights and obligations of the people (including shareholders, officers, and employees) who are associated with a corporation in one way or another. When rights, whether constitutional or statutory, are extended to corporations, the purpose is to protect the rights of these people.").

29 Id.

30 See id.

31 Id. at 2769.

32 Id. at 2797. 


\section{Profit-Making Objective}

The majority found that a profit-making purpose did not preclude such for-profit corporations from exercising religion under the RFRA. ${ }^{33}$ It noted that corporations can have purposes in addition to making a profit. $^{34}$ The majority referenced two prior free exercise cases involving for-profit companies and stated that it would be inconsistent for the Supreme Court to recognize those companies' ability to exercise religion but not Hobby Lobby's, Mardel's, or Conestoga's. ${ }^{35}$ However, neither of these cases addressed the latter issue of whether businesses could exercise religion. In Braunfeld v. Brown, ${ }^{36}$ the Supreme Court dismissed a free exercise claim brought by a for-profit sole proprietorship on the merits rather than for lack of standing. ${ }^{37}$ In Gallagher v. Crown Kosher Super Market, Inc. ${ }^{38}$ a plurality dismissed the free exercise claim brought by four natural persons and a for-profit corporation on the merits without deciding the issue of standing. ${ }^{39}$

\section{Manifestations of Religion}

Finally, the Supreme Court adopted an expansive definition of religious exercise. In particular, it relied on the Religious Land Use and Institutionalized Persons Act of 2000 ("RLUIPA"), which amended the RFRA to include "any exercise of religion, whether or not compelled by, or central to, a system of religious belief." 40 The Court emphasized the RLUIPA's explicit mandate to construe its language "in favor of a broad protection of religious exercise," 41 and held that the "exercise of religion' involves 'not only belief and profession but the performance of (or abstention from) physical acts' that are 'engaged in for religious reasons." 42 Precedent supports that expansive definition. In Wisconsin $v$. Yoder ${ }^{43}$ the Supreme Court held that religious exercise extended beyond worship and belief and encompassed the parties' exercise of religious belief even when it affected a third party. ${ }^{44}$ Religious exercise is not allencompassing, however. The Supreme Court also found that a way of life

${ }^{33} I d$. at $2770-71$ (majority opinion).

34 Id.

35 See id. at 2769 n.21, 2770.

36366 U.S. 599 (1961).

37 Id. at 601.

38366 U.S. 617 (1961).

39 See id. at $618,631$.

40 Hobby Lobby, 134 S. Ct. at 2762 (internal quotation marks omitted).

$41 \mathrm{Id}$.

$42 I d$. at 2770. At the same time, the dissent noted that RFRA incorporated RLUIPA's amended definition of religious exercise, but it did not include the same construction mandate. Id. at 2792 n.10 (Ginsburg, J., dissenting).

43406 U.S. 205 (1972).

44 Id. at $219-20$. 
or philosophy did not warrant protection under the Free Exercise or Establishment Clauses unless "rooted in religious belief." 45 With regard to the law's burden on religion, the majority in Hobby Lobby stated that even a law that makes it more expensive to practice religious beliefs imposes a burden on religious exercise, when applied in the context of a business $^{46}$ - an issue to be explored in the second part of the article.

\section{B. "European" Freedom of Religion}

Over time, freedom of religion claims brought before the European Court of Human Rights have raised some of the most sensitive interpretative issues, a feature the European system appears to share with the Supreme Court case law. In their jurisprudence, the ECHR mechanisms have carved out, gradually and by no means in a linear fashion, answers to a set of questions similar to those that preoccupied the Supreme Court justices in Hobby Lobby: who holds the right to religious freedom, what are manifestations of religion, and what sort of limitations can be imposed on such religious exercise. ${ }^{47}$ Insights into these findings will aid in our de-construction of the Hobby Lobby judgment and the examination of some of its implications.

During the early days of the European human rights project, it was not readily apparent which entities could hold, exercise, and claim freedom of religion. Article 9(1) of the ECHR stipulates that "[e]veryone has the right to freedom of thought, conscience and religion," including "freedom to change his religion or belief and freedom, either alone or in community with others and in public or private, to manifest his religion or belief, in worship, teaching, practice and observance." ${ }^{48}$ Article 34 of Protocol 11, which superseded Article 25 of the ECHR, clarifies the standing requirement:

The Court may receive applications from any person, non-governmental organisation or group of individuals claiming to be the victim of a violation by one of the High Contracting Parties of the rights set forth in the Convention or the protocols thereto. ${ }^{49}$

In determining the list of qualifying entities, the Commission and the European Court decided to expressly exclude governmental organizations, stating that those entities that "exercise governmental powers" can-

45 Id. at 215.

46 Hobby Lobby, 134 S. Ct. at 2770 (citing Braunfeld v. Brown, 366 U.S. 599, 605 (1961)).

47 For the issue of limitations see discussion infra Section II. The analysis in this part and infra p. 30 draws on case law discussed at length in IoANA Cismas, Religious Actors and International LaW 85-93, 99-106, 119-50 (2014).

48 Convention for the Protection of Human Rights and Fundamental Freedoms, art. 9(1), Nov. 4, 1950, 213 U.N.T.S. 221 [hereinafter ECHR].

49 Protocol 11, supra note 4, art. 34. 
not hold and invoke rights under the Convention. ${ }^{50}$ The obvious rightholders of religious freedom, which meet the provisions of the abovecited Article 9 of the ECHR and Article 34 of Protocol 11, are individuals and groups of individuals - the latter may denote unincorporated entities.

But beyond these two cases, can a church that is an incorporated nonprofit entity, a profit-making corporation with some religious or philosophical aims, a for-profit company, and a secular non-profit organization invoke the protection afforded by Article 9 under the ECHR? As we can see, the possibilities for right-holders of religious freedom are numerous, yet the recognized right-holders remain few in the authoritative view of the European mechanisms.

\section{Corporate Form}

In 1968, the very first case in which the Church of Scientology in the United Kingdom, a corporate entity, claimed the right to religious freedom under the ECHR, was swiftly dismissed. ${ }^{51}$ The Commission held that as "a legal and not a natural person," the corporation was "incapable of having or exercising the rights mentioned in Article 9, paragraph 1 of the Convention." 52 In their dismissal, the commissioners considered whether a legal entity or corporation could have or manifest religion. ${ }^{53}$ In $X$ and Church of Scientology v. Sweden, the Commission reversed its denial of religious freedom rights for churches on the following grounds:

When a church body lodges an application under the Convention, it does so in reality, on behalf of its members. It should therefore be accepted that a church body is capable of possessing and exercising the rights contained in Article 9 (1) in its own capacity as a representative of its members . . . Accordingly, the Church of Scientology, as a non-governmental organisation, can properly be considered to be an applicant within the meaning of Article 25 (1) of the Convention. ${ }^{54}$

50 See Holy Monasteries v. Greece, 301-A Eur. Ct. H.R. (ser. A) (1995); Finska Församlingen i Stockholm \& Hautaniemi v. Sweden, App. No. 24019/94, 1996 Eur. Comm'n H.R. Dec. \& Rep. 94. A discussion related to established churches which arguably would have state involvement, which may or may not amount to governmental powers can be found in Cismas, supra note 47, at 88-93.

51 Church of X v. United Kingdom, App. No. 3798/68, 1969 Eur. Comm'n H.R. Dec. \& Rep. 70, http://hudoc.echr.coe.int/eng?i=001-3072.

$52 I d$.

53 Id.

54 X \& Church of Scientology v. Sweden, App. No. 7805/11, 1979 Eur. Comm'n H.R. Dec. \& Rep. 68, 70, http://hudoc.echr.coe.int/eng?i=001-70084. 
The "aggregating of the rights" 55 of individuals lies at the origin of the right of a church to manifest religion. Under this derivative framework, individuals, who are undeniable holders of the right to freedom of religion, set up the church for the principal purpose of collectively manifesting their religion. Therefore, the right of a church to manifest religion stems from the individuals' right to collectively exercise religion. Without acknowledging first, the derivative aspect, and second, the fundamentally religious objective, for which the church was established, "the non-human nature of a legal entity that prevents it from exercising the right to life, for example, would similarly prevent a church from manifesting religion or a humanist organization from exercising beliefs." 56

\section{2. (Non) Profit-making and Religious or Philosophical Objects}

European jurisprudence has consistently illustrated that the religious or philosophical objects derived from the individuals' right to freedom of religion is paramount for the European mechanisms to recognize corporate persons as right-holders of Article 9. For instance, in Company $X v$. Switzerland ${ }^{57}$ - where a limited liability company that ran a printing office in the canton of Zurich complained that the church taxes levied by cantonal authorities represented an infringement of its religious freedom - the Commission dismissed the claim, explaining that:

Even supposing that the applicant's claim may fall within the ambit of Article 9 of the Convention, the Commission is nevertheless of the opinion that a limited liability company given the fact that it concerns a profit-making corporate body, can neither enjoy nor rely on the rights referred to in Article 9, paragraphe 1 [sic], of the Convention. ${ }^{58}$

While the Commission had surely not intended to suggest that there is an epistemological incompatibility between profit and religion, its decision does suggest that in the case of a profit-making company the link to the individuals' right to collectively exercise religion is missing. Likely, the assumption was that an individual establishes a profit-making corporation for the purpose of making profit and not with the goal to further a religious objective.

While such an assumption may be valid in the case of Company $X$, there are two important test cases: the first situation concerns a profit-

55 Carolyn Evans, Freedom of Religion under the European Convention on Human Rights 14 (2001).

56 Recognizing that the collective right of individuals lies at the origin of the church's right to manifest religion does not of course mean that a perfect representation of the church members' interests must exist. See Cismas, supra note 47 , at $100-01$.

57 Company X v. Switzerland, App. No. 7865/77, 1979 Eur. Comm'n H.R. Dec. \& Rep. 86, http://hudoc.echr.coe.int/eng?i=001-74195.

58 Id. at 87. 
making corporation that explicitly listed among its objectives certain religious aims - as Hobby Lobby $\operatorname{did}^{59}$ — and the second concerns a single shareholder and employee of a for-profit corporation that objected to a church levy against the company.

The first case, Kustannus Oy Vapaa Ajattelija $A B$ v. Finland, involved another petition that challenged the levying of a church tax. ${ }^{60}$ In this case, the first applicant was a Finnish publishing company owned by the second applicant, the registered umbrella association of Finnish freethinkers. ${ }^{61}$ The petition claimed that the corporation was established with the purpose of publishing books that promoted the aims of the freethinkers' movement. ${ }^{62}$ It also clarified that, while it had "certain modest economic activities [the company did] not aim at producing profit but at having the Church separated from the State" - in other words, it had some philosophical aims. ${ }^{63}$ While the Commission accepted that the company might have pursued philosophical objects, it held:

For the purposes of domestic law this applicant was registered as a corporate body with limited liability. As such it is in principle required by domestic law to pay tax as any other corporate body, regardless of the underlying purpose of its activities on account of its links with the applicant association and its branches and irrespective of the final receiver of the tax revenues collected from it. ${ }^{64}$

The Commission refused to pierce the corporate veil due to the Freethinkers Association's failure to show that it had been prevented from pursuing the company's publishing activities "in its own name." ${ }^{65}$ In other words, the Association failed to demonstrate that the for-profit corporate form was the only available form under Finnish law that allowed the Freethinkers to pursue their philosophical aim. It is important to note that in Hobby Lobby, the Supreme Court did not examine alternative forms of organizations in which the owners of the three CHCs could have pursued their religious aims.

The second illustrative case involves a single shareholder and employee of a for-profit corporation. The shareholder, an opponent of the church, complained that having to personally pay the church tax levied against her company amounted to an indignity and insult, and requested, given the particular form of her company, that the court pierce the corporate veil and recognize her religious freedom as a ground for church tax

\footnotetext{
59 See discussion infra at pp. 24-25.

60 Kustannus Oy Vapaa Ajattelija AB v. Finland, App. No. 20471/92, 1996 Eur. Comm'n H.R. Dec. \& Rep. 29, http://hudoc.echr.coe.int/eng?i=001-2816.

61 Id. at $43-44$.

62 Id.

63 Id.

64 Id.

65 Id. at 43.
} 
exemption. ${ }^{66}$ This case was decided by Swiss courts; yet in reaffirming its earlier jurisprudence, the Swiss Federal Tribunal relied on the finding of the European Commission on Human Rights in Company $X v$. Switzerland. ${ }^{67}$

The Tribunal chiefly pointed to the financial benefits brought about by the establishment of a corporation, which separates the individual's assets from those of the corporation. ${ }^{68}$ Consequently, it emphasized that the payment of taxes are among the obligations ensuing from such separation between the corporation and the individual. ${ }^{69}$ The Tribunal explained that for the purposes of taxation, corporations and other legal persons have separate burdens from those of the individuals, that is natural persons or shareholders, who comprise them. ${ }^{70}$ As a result of that separate treatment, "the religious freedom of the natural persons behind the activity of a legal person is therefore not relevant in taxation cases" - not even when the natural person is so close, literally speaking, to the legal person. ${ }^{71}$ Interestingly, the Supreme Court has long upheld taxation over claims of religious-based exemptions ${ }^{72}$ because of the compelling government interests taxes serve, but as demonstrated below in Section III, the Court improperly distinguished Hobby Lobby from its precedent on taxation. ${ }^{73}$

Having clarified that the for-profit character of a corporation excludes it from enjoying religious freedom, a second question arises: would nonprofit organizations without religious or philosophical - for lack of a better shorter word, secular - objects be able to hold and invoke Article 9 rights of the ECHR? The Commission, in the case Verein 'KontaktInformation-Therapie' (KIT) and Siegfried Hagen v. Austria, answered the question in the negative as such organizations would not manifest a belief or religion; however, their expressions, thoughts and conscience would be protected under Article 10 of the ECHR. ${ }^{74}$

66 Bundesgerichts [BGer][Federal Supreme Court] Sept. 22, 2010, 2C.71/2010 (Switz.), http://www.servat.unibe.ch/dfr//bger/100922_2C_71-2010.html.

67 Id. II 4.2. See discussion in Cismas, supra note 47, at 102-04.

68 Cismas, supra note 47 , at 102-04.

69 See id.

70 Id.

71 See id. at 103 n.100.

72 See, e.g., United States v. Lee, 455 U.S. 252 (1982) ("Congress drew a line in $\S 1402(\mathrm{~g})$, exempting the self-employed Amish but not all persons working for an Amish employer. The tax imposed on employers to support the social security system must be uniformly applicable to all, except as Congress provides explicitly otherwise.").

73 See Hobby Lobby, 134 S. Ct. at 2803-04.

74 Verein 'Kontakt-Information-Therapie' (KIT) \& Siegfried Hagen v. Austria, App. No. 11921/86, 1988 Eur. Comm'n H.R. Dec. \& Rep. 81. For the distinction drawn, for purposes of Article 9 application, between "thought and conscience" and "religion and belief," see Evans, supra note 55, at 293. 
In conclusion, the European Court and Commission have recognized two undisputable holders of the right to freedom of religion under Article 9 of the ECHR: individuals and groups of individuals. The third rightholder is a corporation of a very specific kind: one that has objectives that are religious or philosophical and not-for-profit. The specific attributes of this corporation reflect that the recognition of this entity as a right-holder depends on the derivation of its right from the rights of individuals to come together and collectively manifest their religion by setting up religious entities. This is the starkest point of contrast between European case law and the finding in Hobby Lobby, through which the Supreme Court has greatly expanded the right-holders of religious freedom in the United States - exactly how much remains to be seen.

\section{Manifestations of Religion}

The ECHR does not define "religion," hence the query is: what are the manifestations of religion? Beyond the ECHR, the absence of a definition of religion is notorious in international law. Natan Lerner observed that "religion, in general, has been too hard to define," which has led drafters of international instruments to opt for "a catalog of rights in the sphere of religion under the heading freedom of thought, conscience, and religion." 75 Freedom of belief and philosophical convictions are the other concepts that form part of the "conflation of terms" in the sphere of religion. ${ }^{76}$ As such, international adjudicative mechanisms, including the European Court, are guided in their interpretation of religious exercise by some central principles and the rights listed in their respective instruments. ${ }^{77}$

There is agreement in doctrine and practice on some central principles: namely, what a definition of religion should not exclude and conversely, what it should exclude. General Comment 22 of the Human Rights Committee ("Comment") illustrates these principles. ${ }^{78}$ The Comment holds that "religion" and "belief" should be understood broadly and are not limited to "traditional religions or religions and beliefs with institutional characteristics or practices analogous to those of traditional religions."

75 Natan Lerner, Religion, Beliefs, and International Human Rights 3 (Religion and Human Rights Series, 2000).

76 Id.

77 John Witte Jr. illustrates the variety of methods which courts embrace to assess what religion is and what it is not. See John Witte Jr., Introduction to Human Rights in Global Perspective: Religious Perspectives xxiv (John Witte, Jr. \& Johan D. van der Vyver eds., 1996); see also ECHR, supra note 48.

78 See U.N. Hum. Rts. Comm., General Comment No. 22, II 2, U.N. Doc. CCPR/C/ 21/Rev.1/Add.4 (Sept. 27, 1993) [hereinafter General Comment No. 22] ("Article 18 protects theistic, non-theistic and atheistic beliefs, as well as the right not to profess any religion or belief.").

${ }^{79} \mathrm{Id}$. 
States and doctrine generally accept that theistic, non-theistic, and atheistic beliefs are included within a definition of religion or belief. ${ }^{80}$ Faced with defining the term "philosophical convictions," the European Court provided some guidelines: these convictions should "attain a certain level of cogency, seriousness, cohesion and importance," be worthy of respect in a democratic society, and should not be incompatible with human dignity. ${ }^{81}$ States generally understand that racism, apartheid, and Nazism should not fall within the definition of religion, belief, or philosophical convictions protected by international law. ${ }^{82}$

The catalogue of rights entailed in the ECHR provides in Article 9 for the right to "manifest his religion or belief, in worship, teaching, practice, and observance." 83 The Declaration on the Elimination of All Forms of Intolerance and of Discrimination Based on Religion or Belief provides a detailed and non-exhaustive list as to what individual and collective religious manifestations may include. ${ }^{84}$

Similar to the Supreme Court, the European mechanisms have adopted an expansive view on religious exercise and are generally reluctant to assess whether religious beliefs are legitimate or reasonable. The Euro-

80 See Elizabeth Odio Benito (Special Rapporteur), Elimination of All Forms of Intolerance and Discrimination Based on Religion or Belief: Study of the Current Dimensions of the Problems of Intolerance and of Discrimination on Grounds of Religion or Belief, II 26, U.N. Doc. E/CN.4/Sub.2/1987/26 (1986), http://documentsdds-ny.un.org/doc/UNDOC/GEN/G86/119/39/pdf/G8611939.pdf?OpenElement;

Natan Lerner, Religious Human Rights under the United Nations, in 2 Religious Human Rights in Global Perspective: Legal Perspectives 79, 131 (Johan D. van der Vyver \& John Witte, Jr. eds., 1996). See also General Comment No. 22, supra note 78 , II 2.

81 Campbell \& Cosans v. United Kingdom, App. Nos. 7511/76 \& 7743/76, 48 Eur. Ct. H.R. 36-37 (ser. A) (1982), http://hudoc.echr.coe.int/eng?i=001-57455.

82 See Donna J. Sullivan, Advancing the Freedom of Religion or Belief through the UN Declaration on the Elimination of Religious Intolerance and Discrimination, 82 Ам. J. INT'L L. 487, 491 \& n.17 (1988).

83 ECHR, supra note 48, art. 9(2).

84 These include: worshipping and assembling in connection with a religion or belief, establishing and maintaining places of worship, appropriate charitable or humanitarian institutions; making, acquiring and using necessary articles and materials related to the rites or customs of a religion or belief; writing, issuing and disseminating relevant publications; teaching a religion or belief in places suitable for these purposes; soliciting and receiving voluntary financial and other contributions from individuals and institutions; training, appointing, electing or designating by succession appropriate leaders; observing days of rest and celebrating holidays and ceremonies in accordance with the precepts of one's religion or belief; establishing and maintaining communications with individuals and communities in matters of religion and belief at the national and international levels. Declaration on the Elimination of All Forms of Intolerance and of Discrimination Based on Religion or Belief, G.A. Res. 36/55, 36 U.N. GAOR Supp. (No. 51) at art. 6 a-i.I, U.N. Doc. A/36/ 51 (1981), http://www.un.org/documents/ga/res/36/a36r055.htm. 
pean Court often states that "but for very exceptional cases, ... [ [the] right to freedom of religion as guaranteed under the Convention excludes any discretion on the part of the State to determine whether religious beliefs or the means used to express such beliefs are legitimate." 85 This statement means that often the European Court itself refuses to pin down whether a manifestation claimed as religious or philosophical fulfills such criteria; instead, the Court seeks to analyze whether the state interference pursued a legitimate aim and was proportional without deciding in the first place whether a breach of the right to manifest religious freedom occurred. ${ }^{86}$ We shall return to this point when we examine permissible limitations on the freedom of religion.

\section{Alternative Paths of Interpretation}

The comparative overview of Hobby Lobby and European case law shows that there is agreement on both sides of the Atlantic for a generous interpretation of religious exercise. Beyond this consensus, the Supreme Court and the European mechanisms diverge on the issue of the rightholder. After Hobby Lobby, US law holds that for-profit CHCs are "persons" that can exercise religious freedom under the RFRA. ${ }^{87}$ On the other hand, the European Court recognizes that only non-profit organizations with religious or philosophical objects (chiefly churches and other religious and freethinker-type organizations) can assert their rights to religious freedom within the meaning of Article 9 of the ECHR. ${ }^{88}$

We posit here that the application of the right to religious freedom to for-profit corporations ignores fundamental aspects of the corporate form as well as organizational privileges and individual protections that emanate from the corporate form as enshrined in US law. Additionally, the Supreme Court's inability to distinguish between non-profit and forprofit organizations ignores US case law and theory that would otherwise enable a more rational, if not perfect, policy on religious freedom. In contrast, the European Court's jurisprudence rightly recognizes corporate particularities and the implications of a for-profit objective.

Although the Supreme Court formally recognized the right to exercise religion only for the CHCs in Hobby Lobby, its rationale has no foreseeable limits, thereby extending such rights to a broader range of corporations. ${ }^{89}$ However, the concept of associational standing, already accepted

85 Hasan \& Chaush v. Bulgaria, App. No. 30985/96, 34 Eur. H.R. Rep. 1339, II 78 (2000).

86 See, e.g., Chappell v. United Kingdom, 152-A 5 Eur. Ct. H.R. (ser. A) (1989); see also Evans, supra note 55, at 283-84.

87 See generally Burwell v. Hobby Lobby Stores, 134 S. Ct. 2751 (2014).

88 See supra Section I(B).

89 The Court claims that it did not create an open door for all corporations to exercise religion, but it provides no rationale for limiting its application in future cases. As Justice Ginsburg noted in the dissent, the Court's "logic extends to 
in US law, could logically limit the recognition of the right to religious freedom to religious non-profit organizations. A similar analysis of collective rights exists in the European Court's acknowledgment of religious rights solely for organizations with religious and philosophical objects.

\section{Legal Separation Between Shareholders and Company in US Law}

Hobby Lobby appears to ignore fundamental aspects of corporate form and its associated privileges. The very purpose of incorporating in the US is to create a separate entity that is distinct from the individuals who comprise the corporation. ${ }^{90}$ The corporation thereby gains special privileges such as legal agency, continuity, and investment incentives through limited liability. ${ }^{91}$ This separation is sacrosanct, and courts only invalidate the separation when the individuals are using corporate form fraudulently or unfairly. ${ }^{92}$ Thus, it is antithetical to corporate form to break the separation between the corporation and its owners, imputing the owners' beliefs to the corporate entity, while still upholding the separation for other formal purposes..$^{93}$

As any first year law student knows, corporate organization in the US necessarily includes a separation between shareholders, directors or officers, and the corporate entity. ${ }^{94}$ The separation between the corporate entity and the natural persons who comprise it - the corporate veil - carries special privileges that enable corporations to profit. ${ }^{95}$ Most fundamentally, the separate corporate entity enables the corporation to

corporations of any size, public or private." Hobby Lobby, 134 S. Ct. at 2797 (Ginsburg, J., dissenting).

90 See Samantar v. Yousuf, 560 U.S. 305, 315 (2010); see also David Millon, Theories of the Corporation, 1990 DukE L.J. 201, 215-16 (describing changes in the theories of incorporation over the 20th century and the rejection of attempts to conceptualize corporations as aggregates of their members). Amici Curiae Corporate and Criminal Law Professors, noted that similar distinctions between corporate entities and the natural persons who comprise the corporation exist in criminal and agency law. Brief for Corporate and Criminal Law Professors as Amici Curiae in Support of Petitioners at 13-16, Sebelius v. Hobby Lobby Stores, Inc., 134 S. Ct. 678 (2013) (Nos. 13-354 \& 13-356), 2014 WL 333889 at *10 [hereinafter Law Professors' Amicus Brief].

91 William T. Allen et al., Commentaries and Cases on the Law of Business Organization 83, 85 (3d ed. 2009). This is the dominant theory of incorporation. For a brief overview of this and other theories of incorporation, see Stephen B. Presser, Piercing the Corporate Veil $§ 1: 2$ (14th ed. 2014).

92 Allen et Al., supra note 91, at 85-86.

93 See, e.g., Diamond Chem. Co. v. Atofina Chem, Inc., 268 F. Supp. 2d 1, 7 (D.D.C. 2003).

94 Allen ET AL., supra note 91, at 85.

95 Id. at 83; see also Seasword v. Hilti, Inc., 537 N.W.2d 221, 224 (Mich. 1995) ("[T]his presumption [is] often referred to as the corporate veil."). 
act in a legal capacity, for example, by entering into binding agreements. ${ }^{96}$ In addition, the separate entity enables the corporation to continue indefinitely and without depending on the natural lives of its officers. ${ }^{97}$ Perhaps the most cited privilege of the corporate veil is that it shields the natural persons from liability for actions of the corporation's management and shields individual assets from creditors. ${ }^{98}$ Under normal circumstances, creditors can only recover from the corporation itself, not from its shareholders or management - a privilege which benefits corporations in many respects. ${ }^{99}$

Despite the quintessence of the corporate veil for the corporation, under rare circumstances, courts may pierce the veil, reaching the assets of the natural persons or attributing the actions of the corporate entity to the natural persons. ${ }^{100}$ Across US state jurisdictions, courts generally examine whether a unity of interest and ownership negates the purported separate personalities of the individual and the corporate entity, in addition (depending on the jurisdiction) to whether there is fraud or unfairness. ${ }^{101}$

For example, the Van Dorn Test, a common test for piercing the corporate veil, requires, first, "such unity of interest and ownership that the separate personalities of the corporation and the individual no longer exist; and second, circumstances must be such that adherence to the fiction of separate corporate existence would sanction a fraud or promote injustice."102 Similarly, the Laya Test requires, first, unity of interest and ownership that negates the separate personalities of the corporation and individual, and second, that inequality or unfairness would exist if the veil were not pierced. ${ }^{103}$

Both tests examine various factors to determine the absence of actual separation between the individuals and the corporate entity. These factors include: noncompliance with corporate formalities (e.g. holding regular meetings, keeping records, maintaining financial records, etc.),

96 Allen ET AL., supra note 91, at 85.

97 Id. at 86.

98 Law Professors' Amicus Brief, supra note 90, at 6.

99 To name just a few benefits, limited liability functionally facilitates investment in corporations, enables stockholders to transfer shares more freely, and allows for a dual system of remote ownership and centralized management. Allen et Al., supra note 91 , at $83-84$.

100 See, e.g., Note, Piercing the Corporate Law Veil: The Alter Ego Doctrine Under Federal Common Law, 95 Harv. L. Rev. 853, 854 (1982).

101 Id.

102 Van Dorn Co. v. Future Chem. \& Oil Corp., 753 F.2d 565, 569-70 (7th Cir. 1985).

103 Laya v. Erin Homes, Inc., 352 S.E.2d 93, 99 (W. Va. 1986). The Laya test also includes an optional third prong that examines how much diligence the other entities made in transacting with the corporation, for example, whether the other entities overlooked the flaws in corporate form. Id. at 100. 
comingling of funds or business assets, undercapitalization, and disregarding boundaries between companies. ${ }^{104}$ In practice, courts look at all of the above factors, but the corporation's (non)adherence to corporate forms greatly affects a court's decision whether to pierce the corporate veil. ${ }^{105}$

The majority in Hobby Lobby essentially pierced the corporate veil for the select purpose of attributing the religious beliefs of the corporations' owners to the corporate entities. ${ }^{106}$ Meanwhile, Hobby Lobby, Mardel, and Conestoga still enjoy the privileges of incorporation and would not meet the standards for piercing the veil with respect to their corporate activities. ${ }^{107}$ The corporations would not meet the second prong of either the Van Dorn or Laya tests, requiring fraud or unfairness, respectively. ${ }^{108}$ Most importantly, the three corporations do not exhibit such "unity of interest and ownership" to negate the separation between the corporations and the owners. ${ }^{109}$ In fact, none of the parties in Hobby Lobby so much as alleged that the corporations did not follow corporate formalities, or any of the other factors that demonstrate unity of interest and ownership. ${ }^{110}$

Admittedly, the classification of Hobby Lobby, Mardel, and Conestoga as CHCs is not entirely irrelevant. Courts rarely pierce the veils of publicly traded corporations - those that sell their stock to the general public - because such corporations are more likely to follow corporate formalities; ${ }^{111}$ but they do so more frequently in the case of CHCs. ${ }^{112}$ The explanation is that $\mathrm{CHCs}$ may have fewer shareholders, ${ }^{113}$ who may have dual roles as corporate officers and investors, ${ }^{114}$ and, as a result, may follow fewer corporate formalities. ${ }^{115}$ The more a CHC (or any corporation) diverges from corporate formalities the more likely it is that a

104 Van Dorn, 753 F.2d at 570; Laya, 352 S.E.2d at 99.

105 See supra note 104.

106 See Burwell v. Hobby Lobby, Inc., 134 S. Ct. 2751 (2014).

107 Id.

108 Van Dorn, 753 F.2d at 570; Laya, 352 S.E.2d at 99.

109 Law Professors' Amicus Brief, supra note 90, at 13-15, 17.

110 See generally Burwell v. Hobby Lobby, Inc., 134 S. Ct. 2751 (2014).

111 Nicholas B. Allen, Note, Reverse Piercing of the Corporate Veil: A Straightforward Path to Justice, 85 ST. JohN's L. REv. 1147, 1151, n. 29 (2011).

112 Hodge O'Neal \& Robert B. Thompson, Close Corporations and LlCs: LAW AND Practice $\S 1: 18$ (Rev. 3d ed. 2015) ("[T]he reality of piercing litigation is that this issue is limited to close corporations."). See generally Robert B. Thompson, Piercing the Corporate Veil: An Empirical Study, 76 Cornell L. Rev. 1036 (1991).

113 As noted in Ginsburg's dissent, though CHCs are commonly conceived as smaller companies, even very large corporations, such as Hobby Lobby, can be closely held. Hobby Lobby, 134 S. Ct. at 2797, n.19 (Ginsburg, J., dissenting).

114 Allen ET AL., supra note 91, at 84.

115 See, e.g., Thomas M. Madden, Identity Confusion and the Close Corporation: Do Corporate Formalities Matter?, 54 R.I. B.J. 5 (2005). 
court will pierce the corporate veil and hold individual shareholders responsible for the actions initially attributed to the corporate entity. ${ }^{116}$ The corporate form, therefore, is essential to the corporations' protections and privileges. It is rather curious that the Supreme Court did not discuss in Hobby Lobby whether the three corporations adhered to the corporate form, only that they were, in fact, CHCs. ${ }^{117}$ Yet, their particular classification as $\mathrm{CHCs}$ alone should not have led to the piercing of their corporate veil.

Another type of for-profit business, the sole proprietorship, is comprised of one person and is not incorporated; as a result, the business is indistinguishable from the owner. ${ }^{118}$ Consequently, it does not need to follow any organizational formalities and does not receive the benefits associated with those formalities such as legal agency (except that which the owner can exercise), continuity, and limited liability. ${ }^{119}$ The Supreme Court could have faced the question of whether a sole proprietorship could exercise religion under the Free Exercise Clause of the First Amendment in Braunfeld v. Brown. ${ }^{120}$ However, the Court did not address that question; instead, without distinguishing between the businesses in question and their owners, it dismissed the case on the merits. ${ }^{121}$

The Court held that the Sunday-closing law in question was constitutional (this was not an RFRA claim) because it was a general law, advancing a secular state purpose, with only an indirect effect on religion, and there were no less burdensome means to pursue its goal. ${ }^{122}$ As we have argued previously, the majority's reliance on this case in Hobby Lobby was far-fetched. Ironically, the effect of Hobby Lobby on whether a sole proprietorship can exercise religion is more direct: given the Court's ruling that a $\mathrm{CHC}$ can exercise religion, it is likely that the sole proprietorship could as well. Therefore, the circle of corporate holders of religious freedom is further expanding.

116 See, e.g., Trustees of Nat'l Elevator Indus. Pension, Health Benefit \& Educ. Funds v. Lutyk, 332 F.3d 188, 195 (3d Cir. 2003) (upholding district court's veil piercing, where there existed a "dearth" of corporate formalities, among other factors); Int'l Union, United Auto., Aerospace \& Agr. Implement Workers v. Aguirre, 410 F.3d 297, 303 (6th Cir. 2005) (upholding district court decision not to pierce the veil where the corporation followed formalities); Judson Atkinson Candies, Inc. v. Latini-Hohberger Dhimantec, 529 F.3d 371, 379 (7th Cir. 2008) (upholding district court decision not to pierce the veil where the only disregard of corporate formalities was failure to file tax returns for certain years).

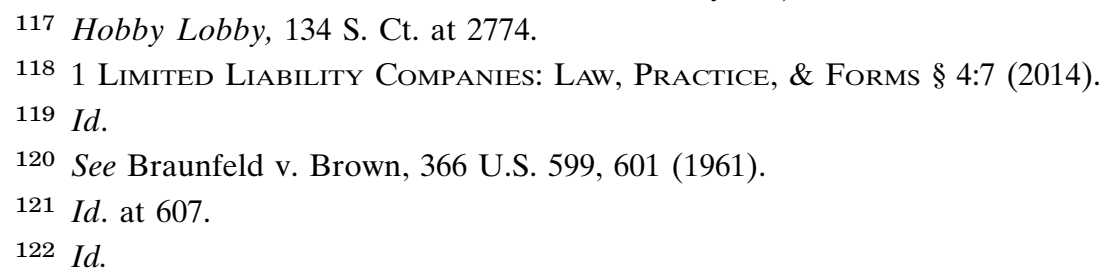


Separately, an entity known as the "corporation sole" is the incorporation of the leader or officer of an organization. ${ }^{123}$ Though uncommon today, the corporation sole requires explanation here because it is often associated with religious organizations. This corporate form, created especially for religious entities to enjoy corporate privileges, maintains a strict separation between the individual, his religion, and the corporate business. ${ }^{124}$ Under English common law, corporations sole were created for religious organizations to hold property and pass it on when new individuals succeeded ecclesiastical positions - in other words, they were given the privilege of continuity just like modern corporations. ${ }^{125}$

Under current US law, some states provide for corporations sole by statute, often explicitly for religious organizations. ${ }^{126}$ They allow, for example, for a newly appointed archbishop of a church to succeed an old one, whereby the corporation sole's assets will continue to be its property. ${ }^{127}$ Meanwhile the old archbishop (or his heirs) will not have any rights to that property. Because the corporation sole is a separate entity from the individual officer, the corporation receives the benefits associated with incorporation - most notably here, the indefinite life of the corporation, but also limited liability and accountability for corporate actions. ${ }^{128}$ On the other hand, corporations sole do not follow most corporate formalities. ${ }^{129}$ Though an anomaly in current law, the corporation sole demonstrates the importance of the separate corporate entity: even a religious figure, incorporated in order to reap the benefits of continuity and legal agency, is examined separately in her business practices from her religious denominational duties and her individual religious beliefs.

The Supreme Court's imputation of the corporate owners' personal beliefs to the corporations in Hobby Lobby ignores the separate corporate entities in a way that parallels - but inverts - the piercing of the corporate veil. The Court stated that "protecting the free-exercise rights of corporations like Hobby Lobby, Conestoga, and Mardel protects the

123 Patty Gerstenblith, Associational Structures of Religious Organizations, 1995 BYU L. ReV. 439, 454 (1995).

124 See, e.g., Wood v. Benedictine Soc'y of Ala., 530 So.2d 801, 805 (Ala. 1988) (refusing to hold a corporation sole - in this case a bishop's incorporation - liable for actions committed by a priest, whose relationship with the bishop was religious, and therefore the priest did not have a business relationship with the corporation sole); Stevens v. Roman Catholic Bishop, 49 Cal.App.3d 877, 123 Cal. Rptr. 171 (Cal. Ct. App. 1975) (holding a corporation sole — also a bishop's incorporation - liable for actions committed by a priest who was acting in the scope of business).

125 Gerstenblith, supra note 123, at 455-56.

126 Id. at $456-58$.

127 Id. at 459-60.

128 James B. O'Hara, The Modern Corporation Sole, 93 Dick. L. Rev. 23, 26 (1988).

1291 William W. Bassett et al., Religious Organizations and the LaW $\S 3: 52$ (2013). 
religious liberty of the humans who own and control those companies." ${ }^{130}$ Although it is true that the corporate entity is a legal fiction, ignoring that separation disregards the form that the owners of Hobby Lobby, Mardel, and Conestoga affirmatively chose for their companies, a form which comes with numerous privileges, including profit-making. ${ }^{131}$ Amici curiae Corporate and Criminal Law Professors described the major inconsistency with the corporations' approach succinctly: "Hobby Lobby[,] [Mardel,] and Conestoga want to argue, in effect, that the corporate veil is only a one-way street: its shareholders can get protection from tort or contract liability by standing behind the veil, but the corporation can ask a court to disregard the corporate veil on this occasion." 132 From a corporate owner's perspective, it is a rather ideal situation; yet even from such perspective, it remains inconsistent with legal theory and previous practice.

\section{Standing}

In Hobby Lobby, the Supreme Court stated that it could not find a reason to prohibit a closely held corporation from exercising religion under the RFRA when it had previously allowed non-profit corporations to do so. ${ }^{133}$ The separation between the corporate entity and its members, as explained above, nevertheless provides a strong reason to exclude corporations. Meanwhile, as we shall see in this section, the concept of associational standing serves as an opportune exception for certain non-profit corporations - both allowing the Supreme Court to follow its past precedent and creating a scheme that parallels the European treatment of religious rights for non-profit entities with religious and philosophical objects.

A long-standing principle in US law generally prohibits a party from bringing a claim on behalf of others. ${ }^{134}$ But this prohibited action is exactly what the corporations in Hobby Lobby attempted since they are distinct corporate entities, and as the Supreme Court recognized, they assert the religious rights of the people who comprise the corporations. ${ }^{135}$ Federal law in the US restricts which entities or natural persons are able to bring suit under the doctrine of standing and requires two components: constitutional standing and prudential standing. ${ }^{136}$

130 Hobby Lobby, 134 S. Ct. at 2768.

131 See id. at 2797 (Ginsburg, J., dissenting).

132 Law Professors' Amicus Brief, supra note 90, at 14.

133 Hobby Lobby, 134 S. Ct. at 2769.

134 See Duke Power Co. v. Carolina Envtl. Study Grp., Inc., 438 U.S. 59, 80 (1978).

135 Hobby Lobby, 134 S. Ct. at 2768.

136 Tacy F. Flint, A New Brand of Representational Standing, 70 U. CHI. L. Rev. 1037, 1037 (2003). 
Article III of the Constitution only gives courts the authority to hear "cases or controversies," 137 which in turn requires that (1) the plaintiff has suffered an "injury in fact," (2) a causal connection exists between the conduct at issue and the injury, and (3) a court's decision can provide redress for the injury. ${ }^{138}$ In addition, under the doctrine of prudential standing, courts exercise restraint, declining to hear cases brought on behalf of third parties, cases involving generalized grievances, and cases that are not within the "zone of interests" that the statute was enacted to protect. $^{139}$

Hobby Lobby, Mardel, and Conestoga each have distinct corporate entities that could file lawsuits on behalf of their own corporate interests. ${ }^{140}$ In order to do so, the corporations would need to show that they have organizational standing, ${ }^{141}$ that is, each of the three corporations must show the three constitutional requirements for standing: injury in fact, causation, and redressibility. ${ }^{142}$ Thus, the organization must demonstrate that "the entity itself suffered a 'concrete injury' to its own interests, apart from any separately identified injury to third parties, such as employees, officers, owners, or shareholders." ${ }^{143}$ Further, the injury in fact cannot be merely an "organizational interest" in the problem. ${ }^{144}$ Because mere interest in the contraception requirement is not enough for organizational standing, the "corporations would have to show 'injury' to their religious exercise"; however, they could not make this showing "except by invoking the beliefs and rights of the separate owners of the corporation." 145

In fact, the Supreme Court, in ruling for the corporations, did just that - it invoked the rights of the natural persons comprising the corporations: "When rights, whether constitutional or statutory, are extended to corporations, the purpose is to protect the rights of people, including shareholders, officers, and employees, who are associated with a corporation in one way or another." 146 Given that there are several narrow doctrinal exceptions to the bar on asserting the rights of others, including associational standing and third party standing, ${ }^{147}$ we will show how neither of these two exceptions would apply in Hobby Lobby. We will

137 U.S. Const. art. III, § 2, cl. 1.

138 Lujan v. Defenders of Wildlife, 504 U.S. 555, 560-61 (1992).

139 Valley Forge Christian Coll. v. Ams. United for Separation of Church \& State, Inc., 454 U.S. 464, 474-75 (1982).

140 Hobby Lobby, 134 S. Ct. at 2768.

141 See id. at 2768 n.13.

142 See Lujan, 504 U.S. at 560-61.

143 Brandon L. Garrett, The Constitutional Standing of Corporations, 163 U. PA. L. Rev. 95, 139 (2014).

144 Sierra Club v. Morton, 405 U.S. 727, 738-39 (1972).

145 Garrett, supra note 143 , at 143.

146 Hobby Lobby, 134 S. Ct. at 2768.

147 See Garrett, supra note 143, at 102. 
also show how associational standing could be the key to distinguishing between religious exercise claims of non-profit versus for-profit corporations.

\section{(i) Associational Standing}

Under the associational standing exception, an organization may have associational standing on behalf of its members if it shows that (1) at least one member would have standing individually, (2) the interests the organization seeks to protect in court are germane to the organization's purpose, and (3) neither the claim nor relief require the individual's participation in the lawsuit. ${ }^{148}$ While the Court in Hobby Lobby found no rationale for distinguishing between non-profit and for-profit corporations' exercise of religion under the RFRA, the associational standing exception could and should have provided a conceptual framework for distinguishing Hobby Lobby from prior cases that accepted that nonprofits could manifest religion. ${ }^{149}$

This exception recognizes the purpose of certain types of organizations where common interests bring individual members together. ${ }^{150}$ In allowing associations to bring claims, the Supreme Court explained that the association is merely "the medium through which its individual members seek to make more effective the expression of their own views." 151 Allowing the association, rather than the members individually, to sue may further serve the members' interests on a practical level because an association may be in a better position to bring a suit. ${ }^{152}$

Associational standing is not unlike the European mechanisms' practice, which recognizes that organizations with religious and philosophical objects can invoke religious freedom under the ECHR. ${ }^{153}$ European practice, we recall, considers that individuals can choose to express their religious freedom collectively in an organized or associational form, and as such, by extension, churches and other religious organizations acquire the right to religious freedom and Article 9 standing before European mechanisms. ${ }^{154}$

As a threshold matter, US jurisprudence allows only groups of people who have come together with a common interest to assert associational standing, but the courts apply fairly loose standards for what constitutes

\footnotetext{
148 Hunt v. Wash. State Apple Adver. Comm'n, 432 U.S. 333, 343 (1977).

149 See Hobby Lobby, 134 S. Ct. at 2769; discussion on associational standing infra this section.

150 Garrett, supra note 143, at 137.

151 NAACP v. Alabama, 357 U.S. 449, 459 (1958).

152 See Garrett, supra note 143, at 138 (citing UAW v. Brock, 477 U.S. 274, 289 (1986)).

153 See discussion supra Section I(B)(2).

154 Id.
} 
an association. ${ }^{155}$ If an association is not a "traditional membership organization," 156 it must serve a particular part of the community, the individuals that make of the association must have the "indicia of membership," and the organization's "fortunes must be tied closely to those of its constituency." 157 It would be a stretch to suggest that Hobby Lobby, Mardel, and Conestoga Woods are membership associations for the purposes of associational standing. However, we now examine associational standing tests in relation to Hobby Lobby to understand why standing is not appropriate in this case, but may be for a religious organization.

If the corporations in Hobby Lobby were associations, it is likely that they would have satisfied the first prong of associational standing, because at least one member of each $\mathrm{CHC}$ would have standing individually. ${ }^{158}$ The Hahns, the family owners of Conestoga, are devout Mennonites who believe that life begins at conception, and oppose contraception that could prevent pregnancy after the fertilization of the egg. ${ }^{159}$ The Greens, the family owners of Hobby Lobby and Mardel, are devout Christians who "believe that life begins at conception and that it would violate their religion to facilitate access to contraceptive drugs or devices that operate after that point." 160

However, the corporate form of Hobby Lobby, Mardel, and Conestoga makes it so that they would have failed to satisfy the second prong of associational standing - that their abilities to exercise their religious beliefs are germane to the organizations' purposes. ${ }^{161}$ The Supreme Court did analyze the purposes of the corporations and found that the references to their religious beliefs in their various organizational documents could indicate non-profit-making purposes. ${ }^{162}$ For example, Conestoga's "Vision and Values Statement" notes that the company aims to make a profit in a manner reflecting the owners' "Christian heritage,"163 and its Board of Directors adopted a "Statement on the Sanctity of Human Life" stating that "life begins at conception" and that it is a sin to terminate life. ${ }^{164}$

Similarly, Hobby Lobby's statement of purpose commits the Board of Directors to "Honoring the Lord in all we do by operating the company in a manner consistent with Biblical principles." 165 The Greens, insofar

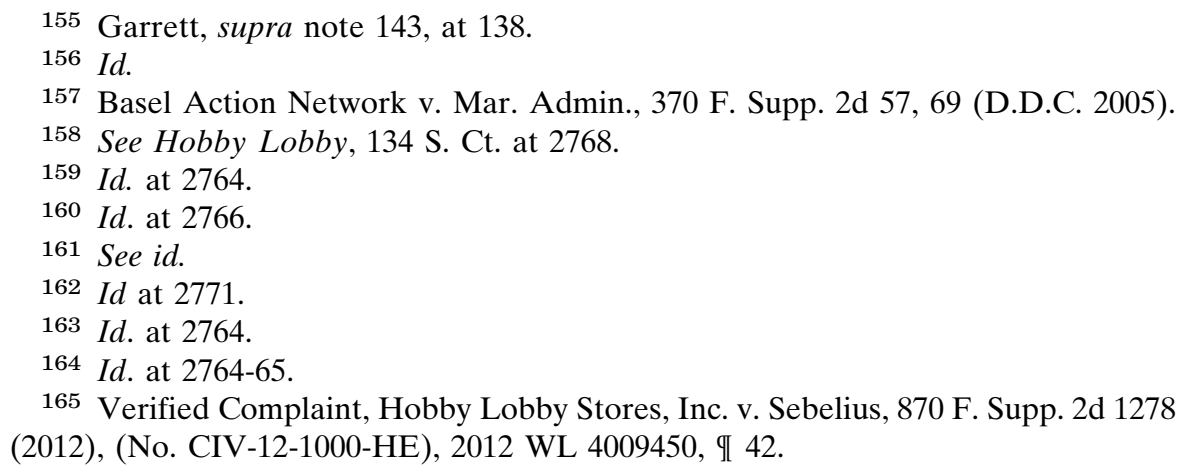


as they operate and manage Hobby Lobby and Mardel, do so, and require their subordinates to do so, in a way that often furthers religious objectives alongside profit-making objectives. ${ }^{166}$ For example, as the Supreme Court noted, they do not operate on Sundays, they do not "facilitate or promote alcohol use," and they purchase proselytizing advertisements in newspapers. ${ }^{167}$

Nevertheless, some valid religious purposes should not be sufficient to override the profit-making form affirmatively chosen by the corporations in Hobby Lobby. The case law of the European mechanisms, namely the case of Kustannus Oy Vapaa Ajattelija AB et al. v. Finland, offers instructive inspiration. ${ }^{168}$ A key inquiry for the European Court is whether the corporate owners had an alternative to the for-profit corporate form for pursuing their religious objects. ${ }^{169}$ Such alternatives were readily available to the Hahns and the Greens in US law, who could have chosen to join a church, or indeed set up their own non-profit religious organization. Had the Hobby Lobby case occurred in Europe, the European Court would have agreed that some of the objects of Hobby Lobby, Mardel and Conestoga are religious, yet this would have been inconsequential for obtaining associational standing, and the CHCs would not have been able to invoke religious freedom. Similarly, we argue, and US law agrees, ${ }^{170}$ that ancillary religious objectives should not be sufficient to override the corporations' for-profit form and render the corporation a conduit for its constituents' (here, individual owners') beliefs.

US case law clarifies that the exercise of religion should be germane to the corporations' purposes under the associational standing test. ${ }^{171}$ The germaneness requirement presents a low threshold for associations to meet. Indeed, courts have created a very permissive rule, redefining "germaneness" to mean only "pertinence." ${ }^{172}$ However, the pertinence requirement stems from the rationale for the associational relationship. In $U A W$ v. Brock, the Supreme Court noted that "[t]he very forces that cause individuals to band together in an association will thus provide some guarantee that the association will work to promote their interests." 173 Based on that rationale, the pertinence test requires that "an

\footnotetext{
166 Hobby Lobby, 134 S. Ct. at 2766.

167 Id.

168 Kustannus Oy Vapaa Ajattelija AB v. Finland, App. No. 20471/92, 1996 Eur. Comm'n H.R. Dec. \& Rep. 29, 40.

169 Id.

170 See Grote Indus. v. Sebelius, 914 F. Supp. 2d 943, 953 (S.D. Ind. 2012) (emphasizing the importance of separating the business purpose of the employers, and employers personal religious inclinations).

171 See, e.g., Hunt, 432 U.S. at 343.

172 Humane Soc'y of the United States v. Hodel, 840 F.2d 45, $55-57$ (D.C. Cir. 1988).

173 Brock, 477 U.S. at 290.
} 
organization's litigation goals be pertinent to its special expertise and the grounds that bring its membership together." 174

This interpretation raises two questions: why did the members of Hobby Lobby, Conestoga and Mardel, respectively come together? Relatedly, would a shareholder seeking to join one of these corporations understand that the corporation's policies would represent or further her manifestation of religion?

On the other hand, religious organizations, which by definition include a congregation brought together for the purpose of manifesting religion, would generally satisfy the requirements for associational standing. The US for-profit corporation, with its legally separate entity, necessarily distinguishes between the individuals within the corporation, thereby making it impossible to represent membership in a lawsuit. ${ }^{175}$ Meanwhile, a non-profit organization is more likely to represent the views of its members. As Brandon Garrett explains:

[A] nonprofit religious organization, functioning in effect as an association, exists to permit religious exercise of members: as the Court puts it, "[f]or many individuals, religious activity derives meaning in large measure from participation in a larger religious community." For the Court to suggest that a for-profit company is no different than a non-profit or an association or a religious entity, and that these distinctions are "quite beside the point," ignores the relevance of the corporate form entirely. ${ }^{176}$

Instead the corporation can sue for its own interests using the organizational standing test; such interests could include maximization of profit, or other corporate goals. However, they cannot include rights that only a natural person and non-profit organizations organized in order for individuals to collectively practice their religious beliefs can exercise because those rights would not be a distinct corporate interest. In other words, extending the right to exercise religion in order "to protect the rights of people, including shareholders, officers, and employees, who are associated with a corporation" requires associational standing, which cannot apply in Hobby Lobby.

\section{(ii) Third Party Standing}

Third party standing doctrine puts a final nail in the coffin for the possibility of Hobby Lobby, Mardel, and Conestoga to have some form of representational standing. As amici curiae Free Speech for People, Auburn Theological Seminary, and Hollender Sustainable Brands noted,

174 Humane Soc'y, 840 F.2d at 56 (emphasis added).

175 Hobby Lobby, 134 S. Ct. at 2768.

176 Garrett, supra note 143, at 145 (citing Corp. of Presiding Bishop of Church of Jesus Christ of Latter-Day Saints v. Amos, 483 U.S. 327, 342 (1987) (Brennan, J., concurring in the judgment)). 
there already exists a separate legal rationale for allowing corporations to sue on behalf of their members - third party standing - which is much more restrictive than associational standing. ${ }^{177}$ The general prohibition on asserting the rights of others is premised on the fact that those who are actually affected are best positioned to adjudicate their claims. Third party standing requires the person bringing the lawsuit to (1) have suffered an "injury in fact" that gives him or her a "sufficiently concrete interest in the outcome of the issue in dispute" and (2) have "a close relation to the third party"; and (3) "some hindrance [must exist] to the third party's ability to protect his or her own interests." 178

In order to allow Hobby Lobby, Mardel, and Conestoga to assert religious exercise rights for the benefit of their owners, the Supreme Court should have examined the corporations' (lack of) fulfillment of the third party standing requirements rather than ignoring the corporate form and imputing the natural persons' beliefs to the corporations. The result would have been unequivocal: the three corporations simply do not meet the third party standing requirements.

It is clear from the judgment that such outcome seemed to pose a conceptual quandary for the majority, because, in their view, the exclusion of a for-profit corporation from exercising religion would create an inexplicable distinction between non-profits and for-profits where the Court has already recognized that some non-profits can exercise religion. ${ }^{179}$ In fact, a logical distinction exists in prior case law on associational standing, and the quandary is rather that the Supreme Court ignored this. Religious non-profit organizations organized in order to collectively practice certain religious beliefs can have standing to assert the religious rights of their members via associational standing while for-profit corporations, which do not have even an informal membership scheme, cannot. ${ }^{180}$

\section{Limitations on Religious Freedom on both sides of the AtLantic}

\section{A. The ACA's Contraceptive Mandate: Testing the Limits}

Having determined that the corporations in Hobby Lobby are persons under the RFRA, and can exercise religion, the Supreme Court then examined the ACA's effect on these corporations: whether it imposes a substantial burden on the exercise of religion, whether it is in furtherance of a compelling government interest, and whether it uses the least restric-

177 Brief for Free Speech for People et al., Conestoga Wood Specialties Corp. v.

Sebelius, 134 S. Ct. 678 (2013) (No. 13-356), 2014 WL 491372, at*19.

178 Powers v. Ohio, 499 U.S. 400, 411 (1991) (internal quotations omitted).

179 Hobby Lobby, 134 S. Ct. at 2769.

180 See supra notes 3-4 and accompanying text. 
tive means to do so. ${ }^{181}$ These issues are of great importance for underscoring some of the socio-legal implications outlined in Section III of this article. Three key points should be mentioned with regard to the Supreme Court's examination of the ACA's effects on religious manifestations.

First, when the Court examined whether the law burdened the exercise of religion, it considered and dismissed an argument that the requirement to offer insurance coverage - which an employee may use to receive a type of birth control that offends the corporations' claimed religious beliefs - was too attenuated to constitute a burden on religious exercise. ${ }^{182}$ The government argued that the law only required insurance coverage, which included the offending methods of birth control, and that several intermediate steps would be required to actually burden the corporations' religious beliefs. ${ }^{183}$ Namely, the employee would have to choose that insurance coverage and seek that medication. These intermediate steps, according to the government, made the burden too attenuated. ${ }^{184}$ Rather than engaging with this argument, the majority merely stated that such an argument would require it to examine the reasonableness of the parties' beliefs. ${ }^{185}$ Longstanding jurisprudence holds that it is not appropriate for courts to determine whether religious beliefs are reasonable, only whether the parties sincerely hold such beliefs. ${ }^{186}$ However, the government's claims did not require the Court to investigate the reasonableness of the defendants' beliefs, but instead to review the causal link between the mandate and the purported harm.

Second, the fact that the Supreme Court decided the case under the RFRA rather than the Free Exercise Clause ${ }^{187}$ has important consequences for the standard of review. The Free Exercise Clause requires a law that has neutral applicability to only undergo rational basis review the government must show that the law is rationally related to an important government interest. ${ }^{188}$ The RFRA on the other hand requires the federal laws to undergo strict scrutiny review - the government must show that there is a compelling government interest and the law utilizes the least restrictive means in pursuing that interest. ${ }^{189}$

\footnotetext{
181 Hobby Lobby, 134 S. Ct. at 2767.

182 Id. at 2777-78.

183 Id. at 2777.

$184 \mathrm{Id}$.

185 See id. at 2778.

186 Id. (quoting Thomas v. Review Bd. of Ind. Emp’t Sec. Div., 450 U.S. 707, 715 (1981)).

187 Under the constitutional avoidance doctrine, US courts will avoid deciding a case on constitutional grounds if another ground (e.g. statutory, standing, ripeness) will suffice. See, e.g., Ashwander v. Tenn. Valley Auth., 297 U.S. 288, 347 (1936).

188 See, e.g., Emp't Div. v. Smith, 494 U.S. 872, 883 (1990).

18942 U.S.C.A. § 2000bb-1 (1993).
} 
In fact, the Court considered at length the necessity of this strict scrutiny standard in free exercise cases in Hobby Lobby. It examined a long history of religious exercise challenges tied to the Free Exercise Clause and determined that Congress intended the RFRA to depart from the free exercise jurisprudence. ${ }^{190}$ Using the strict scrutiny required by the RFRA, the Supreme Court then held that the contraceptive mandate in the ACA was a substantial burden on the exercise of religion, but that it was not the least restrictive means of pursuing the government's interest. ${ }^{191}$ The strict scrutiny standard becomes determinative for religious exercise cases because the least restrictive means requirement is a very high requirement to meet. Thus, the presumption for a case decided under the RFRA, and thus its application of strict scrutiny review, favors individuals asserting their rights to exercise religion. ${ }^{192}$ Here, the Supreme Court did not decide on whether the law served a compelling government interest, the first prong of the strict scrutiny standard, because it found that the law did not utilize the least restrictive means.

Third, the Supreme Court made an analogy between cases related to taxation and Hobby Lobby, and the logical extension of such analogy should have led the Court to dismiss the case for lack of standing. It never should have reached the stage of inquiring whether the contraceptive mandate represented the least restrictive means. The Court used the least restrictive means prong to distinguish Hobby Lobby from prior cases that challenged federal taxes on religious exercise grounds. ${ }^{193}$ It noted that there were no less restrictive means available to implement federal taxes and that individual exemptions were not practical. ${ }^{194}$ In Hobby Lobby, on the other hand, the government could provide insurance directly or could extend already existing exemptions to corporations whose owners hold conflicting religious beliefs. ${ }^{195}$ As noted above, the ECHR mechanisms' taxation cases were key in deciding to whom the

190 Hobby Lobby, 134 S. Ct. at 2772. The RFRA statute was enacted immediately following a Supreme Court case, Employment Division v. Smith, which required facially neutral laws to withstand the strict scrutiny test when challenged under the free exercise clause of the First Amendment. Smith, 494 U.S. at 872. The government in Hobby Lobby argued that Congress passed the statute with the intent to restore the law to the jurisprudence prior to Smith, but the Supreme Court determined that Congress did not demonstrate such intent since it did not use language typically used when tying a statutory interpretation to particular jurisprudence, its later amendments used language inconsistent with that purpose, and it included a clause calling for a broad interpretation of religious exercise - a goal that would be inconsistent with narrowing the application to pre-Smith jurisprudence. Hobby Lobby, 134 S. Ct. at 2772.

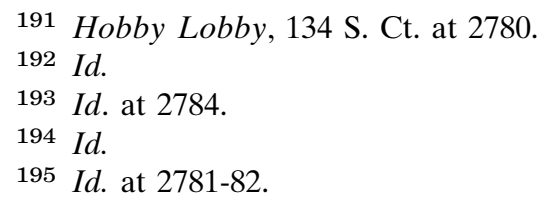


right of freedom of religion belongs. ${ }^{196}$ When examining challenges to church taxes levied against for-profit entities, the fact that the petitioners chose a for-profit model (and the availability of alternative models) determined that the company was not exempt from the church tax. ${ }^{197}$ In another case, a single shareholder of a for-profit corporation was not exempt from a church tax on religious grounds, the Swiss Federal Tribunal reasoned, because a corporate entity has separate obligations from the individual owner. ${ }^{198}$

The Supreme Court, on the other hand distinguished tax cases in determining the permissible limitations on religious freedom. ${ }^{199}$ Yet, the Court could have compared religious freedom and taxation when determining standing - who is able to assert the right to free exercise under the RFRA. Ginsburg noted in her dissent, relying on United States $v$. Lee, that although owners may come together into a commercial enterprise with religious objectives, their beliefs cannot be imposed upon others, such as their employees, through exemption from taxation. ${ }^{200}$ Thus, on the standing question, we posit that the corporate form required a separate treatment of the corporations and the owners, and that the Supreme Court should not have allowed the owners' religious beliefs to be imposed upon the corporations because, among other deficiencies, they were not associations that represent a membership. ${ }^{201}$ If the Court had undertaken the proper analysis in determining standing, it would have dismissed the case and never needed to distinguish Hobby Lobby from taxation cases in the substantive analysis.

\section{B. “European" Limitations on Religious Freedom: On Veils and Margins}

Article 9(2) of the ECHR entails a limitation clause, which provides that states can impose restrictions on religious exercise as long as they are "prescribed by law" and "necessary in a democratic society in the interests of public safety, for the protection of public order, health or morals, or for the protection of the rights and freedoms of others." 202 These provisions therefore call in Article 9 cases for the European Court, and during its existence the Commission, to first assess whether an interference occurred and then to perform a balancing test that verifies whether the state's interference was prescribed by law, whether the interference pur-

\footnotetext{
196 See discussion supra Section I(B) and accompanying text.

197 Kustannus Oy Vapaa Ajattelija AB v. Finland, App. No. 20471/92, 1996 Eur. Comm'n H.R. Dec. \& Rep. 29, 39.

198 Bundesgerichts [BGer][Federal Supreme Court] Sept. 22, 2010, 2C.71/2010

(Switz.), http://www.servat.unibe.ch/dfr//bger/100922_2C_71-2010.html.

199 Hobby Lobby, 134 S. Ct. at 2784.

200 Id. at 2803-04 (Ginsburg, J., dissenting) (citing 455 U.S. 252 (1982)).

201 See supra notes 3-4 and accompanying text.

202 ECHR, supra note 48, art. 9(2).
} 
sues a legitimate aim, and whether it was proportional to the aim. ${ }^{203}$ When the response to any of the three questions of the balancing test is negative, the Court concludes that a violation of the Convention has taken place.

As we have seen, the European Court takes an expansive view of the definition of religion and its manifestations, and generally tends to side with the case applicants (individuals, groups of individuals, and churchlike entities) in what constitutes an interference by the government. ${ }^{204}$ At the same time, due to the supranational nature of the European Court and its sensitivity towards national legislatures, the Court rarely challenges a government's aims as illegitimate. ${ }^{205}$ It allows the state some discretion to make "the initial assessment" concerning "the reality of the pressing social need implied by the notion of 'necessity." "206 Ultimately, it is the proportionality of the interference with the sought aim that becomes paramount in determining whether a violation of Article 9 occurred.

This test under Article 9(2) is certainly not a fail-safe approach: it has produced some quite spectacularly controversial decisions in recent years. ${ }^{207}$ A proportionality test can conceal an underlying evaluation of the legitimacy, or reasonableness, of an applicant's religious belief. ${ }^{208}$ While formally undertaking a proportionality test, European judges have occasionally engaged in what they warned states to avoid - evaluating the legitimacy of an applicant's religious belief. ${ }^{209}$ This practice can be particularly problematic when judges are unable to relate to or fully grasp an applicant's belief. ${ }^{210}$ One of the most important lessons that the European Court may draw from US jurisprudence is to avoid engaging in the

203 Id.

204 See Hasan \& Chaush v. Bulgaria, App. No. 30985/96, 34 Eur. H.R. Rep. 1339, II 78 (2000).

205 See Handyside v. United Kingdom, App. No. 5493/72, 1 Eur. Ct. H.R. 737, II 48 (1976).

206 Id.

207 In particular, the jurisprudence of the European Court on religious symbols has been criticized. For a scholarly assessment, see Jeroen Temperman, The Lautsi Papers: Multidisciplinary Reflections on Religious Symbols in the Public School Classroom (Martinus Nijhoff, The Hague, 2012). For an activist perspective, see European Court ruling on full-face veils punishes women for expressing their beliefs, AMNESTy InTERNATIONAL (July 1, 2014), https:// www.amnesty.org/en/latest/news/2014/07/european-court-ruling-full-face-veilspunishes-women-expressing-their-religion/.

208 Ioana Cismas, Whose Belief: the Plaintiff's or the Judge's? Strategies to Preserve the Impartiality of Judicial Decisions in Cases Relating to Religion, EuropeAn Soc'y INT'L L. Res. F. (May 2013) (on file with author).

209 See, e.g., Dahlab v. Switzerland, App. No. 42393/98, Eur. Ct. H.R. 2001-V (2001).

210 See id. 
evaluation of religious belief, ${ }^{211}$ whether in its assessment of whether an interference occurred or concealed in the proportionality exercise - such an approach may serve as a guarantee of impartiality.

In performing the proportionality test and deciding whether to allow a wide or a narrow "margin of appreciation" to states, the Court searches for a European consensus; in employing this doctrine, the Court reflects its supranational position and recognizes a certain discretion to state parties of the ECHR "in how they implement their obligations [flowing from the Convention], taking into account their historical, social, political and legal specificities." 212

For example, in S.A.S. v. France, a Muslim woman challenged a French law that banned the wearing of a full-face veil and imposed criminal penalties, as an infringement upon her Article 9 right to religious freedom. ${ }^{213}$ The Court's inability to find a European consensus "as to whether or not there should be a blanket ban on the wearing of the full-face veil in public places" led the Grand Chamber to accord a wide margin of appreciation to the French authorities; this deference ultimately resulted in a finding of a non-violation of the applicant's Article 9 rights. ${ }^{214}$

The two dissenting judges noted that as only two out of forty-seven member states of the Council of Europe opted for a full-face veil ban, there was in fact a predominant consensus against a ban. ${ }^{215}$ In their view:

$[\mathrm{T}]$ he blanket ban could be interpreted as a sign of selective pluralism and restricted tolerance. . . . By banning the full-face veil, the French legislature has ... not sought to ensure tolerance between the vast majority and the small minority, but has prohibited what is seen as a cause of tension. ${ }^{216}$

The margin of appreciation doctrine, without further precautions, presents a danger through wide applications, which allow the transposition of government and majoritarian preferences into court interpretation.

Yet, proportionality remains an important test provided that the Court seeks corrections for the European consensus (or lack thereof) acting as a distorting factor in Article 9 cases; it can do this by prioritizing aspects such as the intimate nature of the Convention right at issue in a particular

211 See Carolyn Evans \& Anna Hood, Religious Autonomy and Labour Law: A Comparison of the Jurisprudence of the United States and the European Court of Human Rights, 1 Oxford J. L. \& Religion 81, 82 (2012).

212 Frédéric Mégret, "Nature of Obligations," in International Human Rights LAw 104 (Moeckli, Shah, \& Sivakumaran eds., 2014).

213 See S.A.S. v. France, App. No. 43835/11, Eur. Ct. H.R. (2013), http:// hudoc.echr.coe.int/eng?i=001-145466.

214 Id. II 156.

215 Id. II 16 (dissent). See Uzma S. Burney, European Court of Human Rights Upholds France's Ban on the Full-Face Veil, 19 ASIL Insights 3 (2015).

216 S.A.S. v. France, App. No. 43835/11, Eur. Ct. H.R. II 14 (2013) (dissent). 
case and its importance for the individual, ${ }^{217}$ and by scrupulously avoiding engaging in evaluations of an individual's belief. In other freedom of religion cases, as discussed elsewhere, this doctrine provides better protection of individuals: it has limited the rights of churches and religious organizations to impose religious beliefs and to impose on the rights of religious employees as its aim was to strike a fairer balance between the principle of church autonomy and individuals' equality and labor rights. $^{218}$

\section{Competing Rights: On Majorities and Minorities}

The protection of religious exercise often implicates other individuals' and groups' rights and important public objectives. As a result, both the US and European systems permit limitations on religious exercise in certain circumstances. Both the Supreme Court and the European Court examine the extent of governments' interference with religious exercise to determine whether the restriction is legally permissible.

One can recall that the RFRA invoked the "strict scrutiny" standard, which required the justices to answer three questions: (1) was there a substantial burden imposed upon the corporation through the ACA mandate; (2) was this burden in furtherance of a compelling governmental interest; and (3) was this burden the least restrictive means to pursue those aims. ${ }^{219}$ Similarly under the ECHR, the test involves four questions: (1) was there a limitation on the freedom to manifest religion; (2) was the limitation prescribed by law; (3) was the limitation "necessary in a democratic society" for the protection of various enumerated public goals; and (4) was the limitation proportional to those goals. ${ }^{220}$

The first two questions in the US strict scrutiny standard parallel the first three questions of the European Court's test. They examine governmental limitations, burdens, or harms to religious exercise and the goals such limitations are meant to further. In Hobby Lobby, however, these questions were not paramount in the Supreme Court's interpretation. The Supreme Court assumed that the corporations were substantially burdened, in spite of strong arguments that any interference with the owners' religious exercise was so far removed as to not constitute a significant burden. ${ }^{221}$ The Supreme Court took as sincere the belief that such contraceptives constituted abortion contrary to the owners' religious beliefs, but did not fully explore the impact of the contraceptive mandate

217 See Case of S. \& Marper v. United Kingdom, App. Nos. 30562/04 \& 30566/04,

Eur. Ct. H. R. II 102 (2008), http://hudoc.echr.coe.int/eng?i=001-90051.

218 See Evans \& Hood, supra note 211, at 94; Cismas, supra note 208, at 127-44.

21942 U.S.C.A. § 2000bb-1 (1993).

220 ECHR, supra note 48, art. 9(2).

221 As noted above, the law merely required the corporations to offer the option for employees to choose insurance which covered contraceptives. Hobby Lobby, 134 S. Ct. at 2777-78. 
on those sincere beliefs. In addition, the compelling government interest that the ACA's contraceptive mandate furthered - providing healthcare to women - was never in question and therefore the Supreme Court did not examine it thoroughly.

The last questions in the US and European tests diverge significantly from each other. The Supreme Court does not engage in a proportionality test for RFRA claims. Instead, US courts ask only whether the government action in question is the least restrictive possible way of furthering the compelling government interest. ${ }^{222}$ A determinative part of the decision in Hobby Lobby rested on the fact that the Supreme Court envisioned alternative means of providing access to contraceptive insurance that did not involve Hobby Lobby, Mardel, or Conestoga. ${ }^{223}$ The least restrictive means test, rather than a proportionality test, grants a very narrow margin of appreciation to the US government or, a wide one to the corporation in casu.

On the other hand, in certain recent cases related to religion, the European Court appears to engage in a proportionality test that grants a wide margin of appreciation to governments and a narrow one to those asserting the freedom to manifest religion. ${ }^{224}$ Such cases appear to involve individuals from religious minorities, the paradigmatic illustration being the veiled Muslim woman. ${ }^{225}$

Despite the differences in the tests applied by the Supreme Court and the European Court, one commonality is striking: the outcome of both limitation processes appears to prioritize the interests of the societally powerful - whether, as in Hobby Lobby, it is the corporation that represents a minority of society but holds a majority of the power, or as in S.A.S. v. France, the religious group that represents the majority of society in both numbers and power. And thus, the similar outcome also appears to exacerbate the vulnerability of the vulnerable. Another story that emerges concerns the limitations of religious freedom rights, not of corporations but of the employees of the three CHCs. It is this story that takes center-stage below.

\section{In the Aftermath of Hobby LobBy}

That a court's decision, in particular when such court is the US Supreme Court, can have effects beyond the plaintiffs' situation is not uncommon. Thus, while it similarly has broad consequences, what makes Hobby Lobby extraordinary is the depth of the social and the breadth of the legal consequences.

$222 I d$. at 2767.

223 Id. at 2759-60.

224 See generally S.A.S. v. France, App. No. 43835/11, Eur. Ct. H.R. IIII 81, 83 (2013)

$225 I d$. 


\section{A. Corporate Influence, the Sorting of Society and Polarization}

By recognizing the right to exercise religion of CHCs, Hobby Lobby ignores the potential diversity of religion among the natural persons who comprise a corporation and exacerbates corporate influence ${ }^{226}$ at a societal level, which encourages the further polarization and ideological sorting of business enterprises and discourages individuals' participation in society. The Hobby Lobby decision allows corporations to exercise religious beliefs on behalf of the membership but at the same time ignores the lack of voluntary association with religion by members of a for-profit corporation. As amici curiae Religious Organizations explain in their brief, the US is a pluralistic society with a broad assortment of religions, ${ }^{227}$ and a vast diversity of beliefs exists even among individuals ascribing to the same religion. ${ }^{228}$ These variations are equally prevalent within workplaces, including corporations themselves. ${ }^{229}$

However, unlike religious organizations, corporations do not have the affirmative purpose to associate as a group to manifest religion, generally a specific prescribed doctrine. On the contrary, corporate religious exercise assumes homogeneous beliefs among the members of the corporation and forces the religious association onto members who may not agree with it. ${ }^{230}$ Even the smallest corporation, comprised of only two shareholders, could reveal divergent religious beliefs among the two members. Thus, attributing a particular belief to the corporation in granting standing to sue under the RFRA, US courts impose religious associations on the entire membership.

Such imposition, beyond being legally questionable, can lead to further heightening the societal power of corporations in a time of arguably stag-

226 See generally Dean Baker, The United States Since 1980221 (2007); see also Inequality and Corporate Power, 24(5) Multinational Monitor 8, 9 (2003).

227 Brief of Religious Organizations as Amici Curiae Supporting Respondents at 12, Sebelius v. Hobby Lobby Stores, Inc., 134 S. Ct. 678 (2013) (Nos. 13-354, 13-356), 2014 WL 333898 (citing Pew Forum on Religion \& Pub. Life, U.S. Religious LANDSCAPE SuRvey 2, 36 (2008), http://religions.pewforum.org/pdf/report-religiouslandscape-study-full.pdf).

228 Id at 13 (citing Pew Forum on Religion \& Pub. Life, supra note 227, at 36).

229 Tanenbaum Ctr. for Interreligious Understanding, What American Workers Really Think About Religion: Tanenbaum's 2013 Survey of AMERICAN WORKERS AND RELIGION 5 (2013), http://op.bna.com/dlrcases.nsf/id/ bpen-9b7pks/\$File/2013TanenbaumWorkplaceAndReligionSurveyEmail.pdf.

230 After the US Supreme Court decision in Citizens United v. Federal Election Commission, Frances Hill put forth a similar argument in relation to stockholders who purchase a corporation's stock to make money without the intent of supporting political expression or a particular candidate. Frances R. Hill, Nonparticipatory Association and Compelled Political Speech: Consent as a Constitutional Principle in the Wake of Citizens United, 35 N.Y.U. Rev. L. \& Soc. Change 550, 551-52 (2011) (referencing Citizens United, 130 S. Ct. 876). 
gering corporate influence. ${ }^{231}$ There is a growing trend in the US for corporations and other for-profit entities to influence the public dialogue on social and political issues. ${ }^{232}$ In recent years, corporations have spent unprecedented amounts on political contributions and lobbying efforts. ${ }^{233}$ Interestingly, a report by the Brennan Center released in January 2015 shows that, in the aftermath of Citizens United v. Federal Election Commission, ${ }^{234}$ another landmark decision of the Supreme Court, election spending, including by corporations, has soared..$^{235}$

Increased corporate control over corporate membership - in the form of religious exercise rights - coupled with corporations' increased influence in the public sphere raises the danger of individuals sorting their corporate associations based on their ideological beliefs. ${ }^{236}$ Social scientists have already demonstrated the prevalence of ideological sorting in

231 See supra note 226.

232 See, e.g., Bill Allison \& Sarah Harkins, Fixed Fortunes: Biggest Corporate Political Interests Spend Billions, Get Trillions, Sunlight Found. (Nov. 17, 2014), https://sunlightfoundation.com/blog/2014/11/17/fixed-fortunes-biggest-corporatepolitical-interests-spend-billions-get-trillions/; Lee Drutman, How Corporate Lobbyists Conquered American Democracy, The Atlantic (Apr. 20, 2015), http:// www.theatlantic.com/business/archive/2015/04/how-corporate-lobbyists-conqueredamerican-democracy/390822/; Andrés Martinez, How Big Business Plays Role As Social Activist, S.D. Union TRIB. (July 11, 2015), http://www.sandiegouniontribune. com/news/2015/jul/11/big-business-plays-role-as-social-activist/ (arguing that increased corporate influence on society can be beneficial).

233 See, e.g., Michael Beckel, Top U.S. Corporations Funneled $\$ 173$ Million to Political Nonprofits, CTR. FOR PUB. Integrity (Jan. 16, 2014), http:// www.publicintegrity.org/2014/01/16/14107/top-us-corporations-funneled-173-millionpolitical-nonprofits; Ian Vandewalker, Brennan Center For Justice at New York University School of Law, Election Spending 2014: Outside Spending in Senate Races Since Citizens United 1 (2015); Allison \& Harkins, supra note 232.

234 Citizens United v. Fed. Election Comm'n, 130 S. Ct. 876 (2010).

235 "In the five years since [Citizens United], super PACs, corporations, labor unions, and other outside groups have spent almost $\$ 2$ billion targeting federal elections. That is about two-and-a-half times the total for the years between 1990 and 2008. Outside spending almost tripled between the 2008 and 2012 presidential elections, more than quadrupled between the 2006 and 2010 midterm elections, and then almost doubled again between the 2010 and 2014 midterm elections." DANIEL J. Weiner, Brennan Center For Justice at New York University School of Law, Citizens United Five Years Later 4 (2010).

236 While many commentators refer to this phenomenon as "polarization," a more precise term is "sorting." Morris Fiorina, Americans Have Not Become More Politically Polarized, WAsh. Post (June 23, 2014), http://www.washingtonpost.com/ blogs/monkey-cage/wp/2014/06/23/americans-have-not-become-more-politicallypolarized/. 
the US. ${ }^{237}$ Bill Bishop described this phenomenon in The Big Sort when he analyzed presidential votes, geographic polls, and election results and found that, over the last six decades as Americans have become more geographically mobile, they have moved into areas with like-minded people. ${ }^{238}$ They have geographically sorted themselves into groups according to political beliefs. ${ }^{239}$

This sorting has implications beyond politics, in the area of religious associational life, media, and consumer preferences. An examination of churches reveals political, racial, and economic sorting, as churches attempt to increase membership within their communities. ${ }^{240}$ As a result, the political views within church congregations were also very homogeneous. ${ }^{241}$ Ideological sorting also occurs with regard to individuals' media choices. With the proliferation of cable and internet news sources, individuals are able to curate their news exposure according to political bias, thereby limiting their exposure to news they do not like or news that is related in a manner with which they disagree ${ }^{242}$ - they enclose themselves in an "echo-chamber." 243

Lest we forget, Hobby Lobby and the two other CHCs in the case are businesses with customers - in addition to being the main actors in US legal developments related to religious freedom. As such, of great relevance for understanding the possible consequences of Hobby Lobby is evidence that demonstrates that Americans also sort themselves to some degree in terms of their consumer preferences. ${ }^{244}$ According to a 2012 survey by the Public Religion Research Institute, when given a choice, self-identified liberals are more likely to shop at Target than Walmart, whereas conservatives are more likely to choose Walmart. ${ }^{245}$ A con-

237 See, e.g., Natalie Jomini Stroud, Polarization and Partisan Selective Exposure, 60 J. Cомм. 556, 557 (2010).

238 Bill Bishop, The Big Sort 43-50 (2008).

239 Id.

240 In reference to Christian congregations, see BISHOP, supra note 238, at 171-73.

241 Id. at 176-77.

242 Tom Price, Polarization in America, 24 CQ Researcher 193, 198, 206-08 (2014).

243 See, e.g., Stroud, supra note 237, at 556-57; Nicholas DiFonzo, The EchoChamber Effect, N.Y. Times (Apr. 22, 2011), http://www.nytimes.com/ roomfordebate/2011/04/21/barack-obama-and-the-psychology-of-the-birther-myth/ the-echo-chamber-effect.

244 We note that the studies that show consumer sorting do not address the cause of such sorting, but merely the correlation between political and consumer preferences. It is likely that targeted marketing plays a large role in creating the type of consumer sorting described. Regardless of the cause of such sorting, the fact remains that society is becoming increasingly segmented in a variety of categories. See generally infra notes 245-46.

245 Polarized Holiday Shopping: Are you Target and Starbucks, or Wal-Mart and Dunkin' Donuts?, Pub. Religion Res. InST. (Dec. 19, 2013), http://publicreligion.org/ 
sumer research firm found similar results between Trader Joe's and Whole Foods (both favored by Democrats) and Wal-Mart or Costco (both favored by Republicans). ${ }^{246}$

An anecdote of a 2012 controversy involving fast food chain Chik-fil-A illustrates how the political associations with corporations may affect consumer spending. The controversy erupted when Chik-fil-A's Baptist owner spoke out against same-sex marriage and news broke that the company had donated large sums to anti-gay marriage causes. ${ }^{247}$ Many who disagreed with the action boycotted the chain, while others who supported the owner's anti-gay sentiments, including Republican presidential hopeful Mike Huckabee, promoted "Chik-fil-A appreciation day" and encouraged others to eat there. ${ }^{248}$

Sorting and societal polarization are related because increased ideological sorting exposes individuals to a narrower range of beliefs, which may in turn encourage gradual polarization to more extreme beliefs. ${ }^{249}$ According to one scholar, "there are hundreds of group polarization experiments, all finding that like-minded groups, over time, grow more extreme in the direction of the majority view." ${ }^{250}$ A 2014 Pew Research study shows a widening gap in political beliefs (from liberal to conservative) in the median beliefs of Democrats and Republicans from 1994 to $2014 .{ }^{251}$ The survey further found that individuals held more consistently liberal or conservative beliefs (whereas previously they would have more diverse views on different issues) ${ }^{252}$ and an increased animosity toward the opposing political party. ${ }^{253}$

2013/12/polarized-holiday-shopping-are-you-target-and-starbucks-or-wal-mart-anddunkin-donuts/.

246 Reid Wilson, You Are Where You Shop: What Your Grocery Store Says About You, WAsh. Post (Dec. 9, 2013), http://www.washingtonpost.com/blogs/govbeat/wp/ 2013/12/09/you-are-where-you-shop-what-your-grocery-store-says-about-you/

?hpid=Z5.

247 Kim Severson, Chick-fil-A Thrust Back Into Spotlight on Gay Rights, N.Y. Times (July 25, 2012), http://www.nytimes.com/2012/07/26/us/gay-rights-uproar-overchick-fil-a-widens.html.

248 Id.

249 Alan Abramowitz \& Morris Fiorina, Polarized or Sorted? Just What's Wrong With Our Politics, Anyway?, The Am. Interest (Mar. 11, 2013), http://www.theamerican-interest.com/2013/03/11/polarized-or-sorted-just-whats-wrong-with-ourpolitics-anyway/.

250 Bishop, supra note 238, at 67; see also Stroud, supra note 237, at 569.

251 Nate Cohn, Polarization Is Dividing American Society, Not Just Politics, N.Y. Times (June 12, 2014), http://www.nytimes.com/2014/06/12/upshot/polarization-isdividing-american-society-not-just-politics.html?abt=0002\&abg=1\&_r $=0$.

252 Political Polarization in the American Public, Pew Res. Ctr. (June 12, 2014), http://www.people-press.org/2014/06/12/political-polarization-in-the-american-public/. 253 Id. 
The current trends in ideological sorting and polarization may worsen in the wake of the Hobby Lobby ruling. We use the term ideological sorting here to include both political and religious sorting, because of the ease with which corporations may use religion as a pretext for other beliefs. Because courts will not evaluate the reasonableness of religious beliefs (and rightly so), only their sincerity (and they seem to be very lackadaisical in assessing sincerity), the door remains open for corporations to pursue a variety of agendas under the guise of "religious" beliefs.

After Hobby Lobby, corporations can exert increased influence by asserting their rights to exercise religion in order to opt out of laws. Corporations' further increased influence may encourage potential shareholders and employees to choose their investments and employers, respectively, according to the shareholders' and employees' religious and political beliefs. ${ }^{254}$ These choices would operate as a more conscious form of the ideological sorting that already occurs. Meanwhile, those individuals who are unable to choose their employment, expenditures, or other associations with corporations according their religion will be forced - through their corporate associations - to promote religious beliefs to which they may not ascribe.

That the above scenario is all too real can be grasped from the consequences of the Supreme Court's decision in Citizens United. ${ }^{255}$ In the aftermath of that judgment, members of corporations, including shareholders and employees, have criticized that the corporations with which they are associated have spent money on political causes contrary to the shareholders' and employees' views and that these individuals have no way to limit or control their support of such causes. ${ }^{256}$ Similar results seem probable when for-profit corporations without a religiously convened membership attempt to exercise religion. In some cases, such forced promotion of religious beliefs will drastically interfere with the individual's own human rights, such as through the loss of necessary healthcare benefits. These results will be discussed in greater detail.

Beforehand, it is interesting to parallel the situation in the US with that in Europe. The European Court's practice of according a wide margin of appreciation to states in manifestation of religion claims (the counterpart in the European Court to free exercise claims in the US) preserves facially neutral rules, which in turn tend to support majoritarian views. ${ }^{257}$ As dissenting judges in S.A.S. v. France ${ }^{258}$ and scholars before have

254 Again, we include political beliefs here because religious beliefs could easily be used as a proxy for political beliefs. See id.

255 Citizens United, 130 S. Ct. at 973.

256 WeINER, supra note 235, at 2.

257 S.A.S. v. France, App. No. 43835/11, II 14 (dissent).

258 Id. II 16. 
argued ${ }^{259}$ this approach serves to hide the cause of societal conflict, as opposed to addressing and solving existing tension. One may compare this consequence to that in the US: while US case law granting religious rights to corporations risks increasing polarization, sorting, and corporate power, the European Court's case law granting a wide margin of appreciation for states risks legitimizing the majority's views and obscuring the minority's. This practice seems to be a dangerous path given the rising nationalism in various European countries. ${ }^{260}$

\section{B. Losing the Balance: Women, Employees and "Targeted" Groups}

We now turn to those most obviously affected in the aftermath of Hobby Lobby: women, employees (but not just employees who are women), and minorities who may be the targets of discrimination in the future. The most direct repercussion of the Hobby Lobby decision is that it limits corporate insurance access for women employees of CHCs. To be clear, the majority's decision has the direct effect of denying Hobby Lobby, Mardel, and Conestoga's employees' corporate insurance access to certain forms of birth control, but that will not necessarily be Hobby Lobby's long-term legacy. ${ }^{261}$

The Supreme Court found that the contraceptive mandate of the ACA violated the RFRA because the government had a less restrictive means of ensuring women's access to birth control: either through direct government payment or through government sponsored exchanges that it had already made available to religious organizations who objected to the law. ${ }^{262}$ Hobby Lobby, Mardel, and Conestoga's employees' access contraceptive insurance coverage may be restored when the government implements a less restrictive alternative.

Despite some hope for future government intervention, the immediate effects are vast. The decision has the potential to affect female employees of Hobby Lobby, Mardel, and Conestoga as well as the employees' spouses and dependents. Moreover, the decision immediately affects the

259 Steven Wheatley, for instance has observed that European Court "has recognised the legitimacy of claims by minorities to distinctiveness in the face of cultural homogeneity but abrogated any responsibility to intervene in majority/ minority disputes." Steven Wheatley, Minorities under ECHR and the Construction of a "Democratic Society," 4 Pub. L. 770, 771 (2007); see also Stephanie E. Berry, A Tale of Two Instruments: Religious Minorities and the Council of Europe's Rights Regime, 30 Neth. Q. Hum. RTs. R. 1, 10 (2012).

260 See, e.g., Myles Udland, There's a New Political Risk Looming in Europe, Bus. INSIDER (Sept. 6, 2015), http://www.businessinsider.com/european-nationalism-risk2015-9; Luke Baker \& Stephen Adler, "Nationalism and Xenophobia" on Rise Ahead of European Elections, REUTERs (Oct. 30, 2013), http://www.reuters.com/article/2013/ 10/30/us-eu-parliament-elections-idUSBRE99T0YZ20131030.

261 See Hobby Lobby, 134 S. Ct. at 2775, 2782.

$262 I d$. 
employees of eighty-two other CHCs that had pending challenges to the ACA's contraceptive mandate. ${ }^{263}$ The decision has the further potential to affect healthcare access for all other CHCs' employees if their owners object to the law, and, as mentioned above, there is no logical legal rationale that would keep this decision from applying to other forms of forprofit corporations. ${ }^{264}$

The Supreme Court's decision substantively diminishes women's access to necessary healthcare. Most visibly, it affects access to birth control when there are no alternatives to the four challenged forms, whereby two of the challenged forms are the most effective options of non-permanent birth control; as such, an equivalent alternative does not exist. ${ }^{265}$ Even in situations where other forms of birth control could be appropriate, the Hobby Lobby judgment enables the employer to limit the options, rather than leaving the personal and medical decision to the woman and her doctor. ${ }^{266}$ This restriction in choices has significant effects for reproductive rights and for healthcare more generally: it relocates the decisionmaking nexus away from those who are in the best position to make the decision and disempowers them.

Aside from reproductive healthcare and agency over its provision of being a right in itself, the related societal effects are vast, as limitations in this area are intrinsically linked with access to other rights. The Supreme Court itself highlighted in Planned Parenthood v. Casey that " $[\mathrm{t}]$ he ability of women to participate equally in the economic and social life of the Nation has been facilitated by their ability to control their reproductive lives." 267

Furthermore, various religious beliefs could impose restrictions on a wide variety of other healthcare approaches. The dissent pondered whether the majority would extend its ruling in cases involving "religiously grounded objections to blood transfusions (Jehovah's Witnesses); antidepressants (Scientologists); medications derived from pigs, including anesthesia, intravenous fluids, and pills coated with gelatin (certain Muslims, Jews, and Hindus); and vaccinations (Christian Scientists, among

263 Abby Haglage, After Hobby Lobby, These 82 Corporations Could Drop Birth Control Coverage, The DAILy BeAst (June 30, 2014), http://www.thedailybeast.com/ articles/2014/06/30/after-hobby-lobby-these-77-corporations-will-drop-birth-controlcoverage.html; see also Jaeah Lee, It's Not Just Hobby Lobby: These 71 Companies Don't Want to Cover Your Birth Control Either, Mother Jones (Apr. 2, 2014), http:// www.motherjones.com/politics/2014/04/hobby-lobby-sebelius-contraceptive-forprofit-lawsuits\#cases.

264 Hobby Lobby, 134 S. Ct. at 2797 (Ginsburg, J., dissenting).

$265 I d$. at 2800.

266 See id. at 2799.

267 Planned Parenthood of Southeastern Pennsylvania v. Casey, 505 U.S. 833, 856 (1992). 
others)." The majority did not offer a convincing logical distinction to eliminate that worry. ${ }^{268}$

While ignoring the discriminating effects on women in the form of healthcare inequality, the Hobby Lobby decision has the potential of sanctioning wider practices of discrimination against other groups in the name of religion. Even before the Supreme Court's ruling in Hobby Lobby, the case has been rhetorically tied to discussions on lesbian, gay, bi-sexual, transgender, and queer ("LGBTQ") rights. ${ }^{269}$ Many of the more vocal opponents of LGBTQ rights voice their opposition using religious grounds.

In particular, several recent cases have involved storeowners who refused to provide their services to gay customers on religious grounds. In Elane Photography, LLC v. Willock ("Elane Photography"), a New Mexico photography company refused to photograph a commitment ceremony between two women. ${ }^{270}$ The New Mexico Supreme Court determined that the company unlawfully discriminated against the couple pursuant to the New Mexico Human Rights Act, despite the religious nature of the owner's objections, because the company sold its photography services to the general public. ${ }^{271}$ The Supreme Court denied certiorari to review the decision in April of 2014, just months before the Hobby Lobby decision. ${ }^{272}$

In the aftermath of Hobby Lobby, Terri Day, Leticia Diaz, and Danielle Weatherby argue that Elane Photography and numerous cases filed since represent a "growing trend in which for-profit businesses are invoking their deeply held religious beliefs to excuse themselves from serving gay and lesbian customers" as well as an example of the potential slippery slope for the religious exercise protections the Supreme Court recognized in Hobby Lobby. ${ }^{273}$ This trend even extends to government employees. For example, in September 2015, County Clerk Kim Davis, of Rowan, Kentucky, cited her religious beliefs when she refused to issue marriage licenses to same-sex couples. ${ }^{274}$ Moreover, Day, Diaz, and Weatherby

268 Hobby Lobby, 134 S. Ct. at 2805 (Ginsburg, J., dissenting).

269 We use this term in an effort to describe groups of people who are commonly the subjects of discrimination, in particular trying to encompass much of the discrimination that is most apparent in the wake of Hobby Lobby, but note that the term does not represent a homogeneous community with singular issues and values.

270 Elane Photography v. Willock, 309 P.3d 53, 59 (N.M. 2013), cert. denied, 134 S.

Ct. 1787 (2014).

271 Id.

272 Id.

273 Terri R. Day et al., A Primer on Hobby Lobby: For-Profit Corporate Entities' Challenge to the HHS Mandate, Free Exercise Rights, RFRA's Scope, and the Nondelegation Doctrine, 42 PePp. L. Rev. 55, 96 (2014).

274 Alan Blinder \& Tamar Lewin, Clerk in Kentucky Chooses Jail over Deal on Same-Sex Marriage, N.Y. TIMES (Sept. 3, 2015), http://www.nytimes.com/2015/09/04/ us/kim-davis-same-sex-marriage.html. 
note that numerous states have enacted state-level RFRA laws that "essentially grant religious employers a waiver from complying with state public accommodations laws." ${ }^{275}$ These trends threaten to sanction religious exercise claims as a pretext to discriminate against LGBTQ individuals, and the Hobby Lobby decision, in recognizing corporate religious exercise rights even where such rights negatively impact individuals, opens the door wider for such claims to move forward.

Traditionally, the limits of religious exercise in the US can be understood by the oft-quoted saying, "[y]our right to swing your arms ends just where the other man's nose begins." ${ }^{276}$ However, because the Supreme Court decided Hobby Lobby using the strict scrutiny standard, the decision did not rest on the harmful effects the exemption would have on employees. ${ }^{277}$ Instead, it rested on the level of government intrusion into the corporations' operations. ${ }^{278}$ Because US law requires the government to use the least restrictive means, it promotes individual (or corporate) autonomy over the protection of other rights. ${ }^{279}$ In Hobby Lobby, the test favored corporations at the expense of women and employees and their access to healthcare. In the future, it risks favoring corporations at the expense of promoting discrimination against other groups.

\section{CONCLUSION}

In the aftermath of the Supreme Court's judgment in Burwell v. Hobby Lobby Stores, many will agree that Hobby Lobby's most remarkable legacy may not be in the area of arts and crafts, but in that of US law. Since the Supreme Court's holding, we have a new right holder of freedom of religion: the for-profit corporation. This, in and of itself, is extraordinary - at a metaphysical level. As this article has argued, recognizing the freedom of religion of corporations will have negative legal consequences on the reproductive and healthcare rights of certain groups of individuals in casu and beyond (women, employees). It will likely legitimize discriminatory conduct by corporations towards LGBTQ individuals and deepen societal repercussions in the form of ideological sorting and polarization.

We have demonstrated that the Supreme Court decision is misguided in its approach (or lack thereof) to the corporate form, standing, and to a certain extent, limitations on religious freedom. It sidesteps a rich body of case law on corporate form that would recognize the separation of the corporate entity from its officers. Instead, it confers the owner's beliefs onto the corporation itself, a tactic that would be useful under the associational standing doctrine but would not apply to Hobby Lobby. In addi-

$275 I d$.

276 Hobby Lobby, 134 S. Ct. at 2795 (Ginsburg, J., dissenting) (quoting Zechariah Chafee, Jr., Freedom of Speech in War Time, 32 Harv. L. Rev. 932, 957 (1919)).

277 Hobby Lobby, 134 S. Ct. at 2766 (majority opinion).

278 Id.

279 Id. at 2751. 
tion to its misguided conclusion on whose right is the free exercise of religion, the standard the Supreme Court uses to determine when the free exercise of religion can be limited under the RFRA overwhelmingly favors those claiming the rights.

Alternative ways in US law were available, and inspiration from the European Court could have provided valuable insights for an alternative model. These alternatives include a distinction between non-profit and for-profit enterprises and a recognition that only corporations whose membership came together for the purpose of exercising religion - in other words associations - should be able to assert religious beliefs on behalf of their membership.

Nevertheless, the European model has its own problems of favoring majoritarian views on religion at the expense of individual religious liberty. Thus, our question of who's right, the Supreme Court versus the European Court, does not have a clear-cut answer. While the Supreme Court should have denied corporate freedom of religion, the European model goes too far in the opposite direction. In particular in the area of limitations on religious rights, both courts' recent bodies of jurisprudence favor societally powerful groups. In the US, that jurisprudence serves to entrench the privileges of increasingly powerful corporations, while in Europe it serves to fortify majoritarian interests.

Going forward, the Supreme Court may insist on restricting freedom of religion to the specific case of CHCs. However, this restriction seems to us legally untenable. Sole proprietorship would have a stronger case to make based on the reasoning in Hobby Lobby. The sound alternative is to revisit Hobby Lobby and return to the precedent of for-profit corporate religious freedom. Given that some corporations will feel legitimized to discriminate against LGBTQ individuals in the name of religious freedom, the Supreme Court may have such an opportunity in the not so distant future. This opportunity may be the most ironic consequence of Hobby Lobby as the Court will have to address head-on the two critical questions of contemporary times and conclude that corporate rights come with responsibilities and that the state must protect individuals from religious interference, even when such interference is exerted by corporations. 